\title{
The bi-directional exchange of oxygenated VOCs between a loblolly pine (Pinus taeda) plantation and the atmosphere
}

\author{
T. Karl ${ }^{1}$, P. Harley ${ }^{1}$, A. Guenther ${ }^{1}$, R. Rasmussen ${ }^{2}$, B. Baker ${ }^{3}$, K. Jardine ${ }^{3}$, and E. Nemitz \\ ${ }^{1}$ National Center for Atmospheric Research, Boulder, Colorado, USA \\ ${ }^{2}$ Oregon Health and Science University, Oregon, USA \\ ${ }^{3}$ South Dakota School of Mines and Technology, Rapid City, South Dakota, USA \\ ${ }^{4}$ Centre for Ecology and Hydrology, Edinburgh, UK
}

Received: 1 July 2005 - Published in Atmos. Chem. Phys. Discuss.: 11 August 2005

Revised: 26 October 2005 - Accepted: 26 October 2005 - Published: 10 November 2005

\begin{abstract}
Using new in-situ field observations of the most abundant oxygenated VOCs (methanol, acetaldehyde, acetone, $\mathrm{C}_{3} / \mathrm{C}_{4}$ carbonyls, MVK $+\mathrm{MAC}$ and acetic acid) we were able to constrain emission and deposition patterns above and within a loblolly pine (Pinus taeda) plantation with a sweetgum (Liquidambar styraciflua) understory. During the day canopy scale measurements showed significant emission of methanol and acetone, while methyl vinyl ketone and methacrolein, acetaldehyde and acetic acid were mainly deposited during the day. All oxygenated compounds exhibited strong losses during the night that could not be explained by conventional dry deposition parameterizations. Accompanying leaf level measurements indicated substantial methanol and acetone emissions from loblolly pine. The exchange of acetaldehyde was more complex. Laboratory measurements made on loblolly pine needles indicated that acetaldehyde may be either emitted or taken up depending on ambient concentrations, with the compensation point increasing exponentially with temperature, and that mature needles tended to emit more acetaldehyde than younger needles. Canopy scale measurements suggested mostly deposition. Short-term (approx. $2 \mathrm{~h}$ ) ozone fumigation in the laboratory had no detectable impact on post-exposure emissions of methanol and acetone, but decreased the exchange rates of acetaldehyde. The emission of a variety of oxygenated compounds (e.g. carbonyls and alcohols) was triggered or significantly enhanced during laboratory ozone fumigation experiments. These results suggest that higher ambient ozone levels in the future might enhance the biogenic contribution of some oxygenated compounds. Those with sufficiently low vapor pressures may potentially influence secondary organic aerosol growth. Compounds recently hypothesized to be primarily produced in the canopy atmosphere via ozone plus terpenoid-type reactions can also originate from the oxida-
\end{abstract}

Correspondence to: T. Karl

(tomkarl@ucar.edu) tion reaction of ozone with leaf surfaces and inside the leaf. This needs to be taken into account when scaling up very reactive biogenic compounds.

\section{Introduction}

The emission of biogenic volatile organic compounds (VOC) is recognized as the largest terrestrial source of reactive carbon to the atmosphere (Guenther et al., 1995). While significant emissions of oxygenated VOC (OVOC) from plants are generally acknowledged, their budgets remain very uncertain (Heikes et al., 2002; Singh et al., 2004). Biochemical pathways for the production of some of these oxygenated compounds have recently been elucidated by various groups and reviewed by Fall (2003). For example, methanol is produced in plants from demethylation of pectin and attributed to plant cell wall growth and repair. While acetone is believed to originate from cyanogenesis and the decarboxylation of acetoacetate, acetaldehyde has been shown to be emitted as a result of the oxidation of ethanol arising in anoxic tissues (Kreuzwieser et al., 2000). Labeling studies using ${ }^{13} \mathrm{C}$ suggest that acetaldehyde can also originate from recently fixed carbon and could be produced from cytosolic pyruvate, which could trigger its formation under rapidly changing light conditions (Karl et al., 2002a; Graus et al., 2004) have hypothesized that Acetyl-Co A might also be linked to the production of acetaldehyde and related to wound VOCs (Fall et al., 1999; Hatanaka, 1996).

Emissions of aldehydes and ketones have been observed from various plants, but in most cases only limited qualitative assessments are available above forests (Steinbrecher and Rabong, 1994; Janson et al., 1999). Compensation point and canopy scale measurements of OVOCs are still extremely scarce (Kesselmeier, 2001). Rottenberger et al. (2004) reported the compensation point of acetaldehyde for three tropical tree species and its variation between wet and dry

(C) 2005 Author(s). This work is licensed under a Creative Commons License. 
seasons. Cojocariu et al. (2004) presented similar measurements for Norway Spruce (Picea abies) using branch enclosures. Schade and Goldstein (2001) observed high fluxes of methanol, acetone and acetaldehyde above a plantation of ponderosa pine (Pinus ponderosa) and investigated plantphysiological influences on these emissions (Schade and Goldstein, 2002). Similarly, Spirig et al. (2005) found significant methanol fluxes from a temperate ecosystem. Seasonal variations in biogenic OVOCs above a North American deciduous forest in Michigan were attributed to a combination of senescing and growing vegetation (Karl et al., 2003). Overall these studies provide experimental evidence that the emission of compounds such as methanol, acetaldehyde and acetone exhibit a complex emission/deposition behavior. It is now also recognized that these compounds can be released from decaying plant material (Warneke et al., 1999), naturally drying grass (Karl et al., 2005) and crops (Schade and Custer, 2004).

Holzinger et al. (2004) recently reported the presence of a large number of higher molecular weight compounds $(>100 \mathrm{amu})$ in the air within and above a ponderosa pine plantation and speculated that they were exclusively products of reactions between ozone and highly reactive terpenoids, many of which were undetected, that were emitted from the forest. While some of these compounds may originate from gas phase terpenoid oxidation with ozone (Calogirou et al., 1999), some are also known to be formed from the reaction of ozone with leaf surfaces (Fruekilde et al., 1998; Wildt et al., 2003). It is still not clear which of these processes is the dominant source of oxygenated species observed in forest atmospheres, especially in the higher mass range (e.g. > $100 \mathrm{amu}$ ).

Recently, various parameterizations have been incorporated into global chemistry and transport models in order to constrain biogenic OVOC emissions and derive budget estimates (Jacob et al., 2002). While complex plant physiological models (Niinemets et al., 2004) are being developed, a semi-mechanistic model has been used to assess the global budget of methanol (Galbally and Kirstine, 2002). Global and regional chemistry models typically incorporate an exponentially increasing temperature dependence for the emissions of all VOC, including those of OVOC. However, whether OVOCs are emitted or deposited depends on their relative concentrations within the leaf and in the atmosphere outside the leaf boundary layer. The rate of OVOC production, and thus the compensation point, depends on many parameters such as enzyme activities, stress and nutrient levels, and may vary seasonally. In order to model the exchange of these compounds and constrain regional and global budgets, combined investigations of process level and canopy scale studies are a crucial link in order to develop accurate emission algorithms. Here we present results from the recent CELTIC (Chemical Emission, Loss, Transformation and Interaction within Canopies) field study in the eastern US above a loblolly pine (Pinus taeda) plantation with a sweetgum (Liquidambar styraciflua) understory. Using a combi- nation of leaf and canopy level measurements we investigated the bi-directional exchange of the most abundant oxygenated compounds.

\section{Experimental}

\subsection{Laboratory leaf level measurements}

Young saplings of loblolly pine (Pinus taeda) and sweetgum (Liquidambar styraciflua) were purchased in 2004 from Forestfarm Nursery (Williams, OR, USA) and maintained in the NCAR Frost Phytotron. Leaf gas exchange measurements were made using a commercial leaf photosynthesis system (MPH-1000, Campbell Scientific, Logan, UT, USA) in conjunction with a temperature-controlled glass leaf enclosure constructed in house. Humidifed and dry zero air (Zero Air Generator) were mixed with $\mathrm{CO}_{2}(16700 \mathrm{ppmv}$ in zero air) using mass flow controllers (Model 824, Edwards High Vacuum, MA) to generate a gas stream of known $\mathrm{CO}_{2}$ concentration and dew point, free of $\mathrm{O}_{3}$, which was passed to the enclosure. Flow rate of air flowing into the enclosure was measured with a mass flow controller (Model 824, Edwards High Vacuum, MA). The difference in $\mathrm{CO}_{2}$ and $\mathrm{H}_{2} \mathrm{O}$ vapor partial pressures between air entering and leaving the enclosure was measured with an infrared gas analyzer (LI6262, Li-Cor, Lincoln, NE) in differential mode. The dew point of air entering the enclosure was measured using a dew point mirror (General Eastern, Watertown, MA). Rates of net photosynthesis, transpiration and stomatal conductance were calculated according to Farquhar et al. (1980).

The enclosure consisted of an upper and lower chamber, each consisting of a glass cylinder $(8 \mathrm{~cm}$ diameter) enclosed on one end (total volume $=$ approx. $300 \mathrm{~cm}^{3}$ ). A small hole in the lower chamber accommodated the shaft of a fan motor (ESCAP Model 22N28, Danaher Motion, Wood Dale, IL) to which was attached a plastic fan blade $4 \mathrm{~cm}$ in diameter (Micronel, Vista, CA). Leaves or needles were inserted between the two chamber halves, sandwiched between two 1/8-inch closed cell foam gaskets. Incident photosynthetically active radiation (PAR) was measured outside the enclosure with a photodiode calibrated against a PAR quantum sensor (LI-192 Li-Cor, Lincoln, NE), and leaf temperature was measured using a copper-constantan thermocouple (Omega Engineering, Stamford, $\mathrm{CN}$ ) appressed to the bottom of the leaf (in the case of sweetgum) or placed in close proximity to a needles in the case of loblolly pine. Temperature control $\left( \pm 0.2^{\circ} \mathrm{C}\right.$, between $20^{\circ} \mathrm{C}$ and $45^{\circ} \mathrm{C}$ ) was achieved using two Peltier thermoelectric coolers sandwiched between the bottom of the enclosure and an air cooled heat sink.

Optionally a photolytic $\mathrm{O}_{3}$ source was inserted either before or after the plant chamber to assess the effect of ozone fumigation. Ozone concentrations in air entering and exiting the enclosure were measured by UV absorption (Model 202, 2B Technologies, USA). Blank tests using the empty glass 
cuvette showed no significant increase of background concentrations for compounds above $75 \mathrm{amu}$ after the addition of ozone ( $<20 \%$ change). The VOC increase associated with the Teflon lines was small in comparison to the VOC increase associated with a plant inside the glass cuvette during ozone fumigation $(<10 \%)$. In addition, measuring ozone immediately before and after the cuvette minimized any contribution associated with Teflon tubing during ozone fumigation. For some oxygenated compounds (e.g. acetaldehyde, acetone) however, we observed significantly increased concentrations due to artifact formation in the blank experiment. For example the acetaldehyde (acetone) background could increase by as much as 2 (1) ppb after adding ozone through the empty sampling system compared to an increase of 4-8 (3-5) ppb when a plant was inserted in the cuvette. A study evaluating the role of heterogeneous oxidation of alkenes in the detection of atmospheric acetaldehyde (Northway et al., 2004) found similar artifact problems for Teflon lines.

An ozone fumigation and reactivity experiment was typically performed in the following sequence: (1) measurement of steady state VOC emissions in ozone free air; (2) ozone addition before the plant chamber until VOCs exiting the plant chamber reached steady state, (3) turn off ozone and wait until VOCs exiting the plant chamber were in steady state again, (4) insert a second glass reaction chamber, similar in volume to the leaf enclosure, in the gas line exiting the enclosure, (5) generate ozone in the line between the plant chamber and the second reaction chamber, and measure VOC composition exiting the second chamber, (6) turn off ozone and wait until VOC emissions were approx. in steady state again. Each experiment lasted approx. 20-40 min. The two pathways were tested to determine the effects of ozone on the leaf surfaces separate from the ozone reactions with the gas-phase emissions. Ozone was produced in line and no dilution was necessary. After the ozone source was turned off, all VOCs concentrations quickly returned to the initial conditions.

In order to determine a compensation point, which is defined as the ambient concentration level above which the plants takes up VOCs, the inlet air concentration of methanol, acetaldehyde and acetone was varied between 0 and $12 \mathrm{ppb}$. After each experiment the needles or leaves were harvested for determination of their dry weight and/or leaf area.

\subsection{Field site description and experimental details}

The CELTIC (Chemical Emission, Loss, Transformation and Interaction within Canopies) experiment was conducted at Duke Forest C-H2O, an experimental loblolly pine plantation (average tree height $18 \mathrm{~m}$ ) in North Carolina $\left(35.98^{\circ} \mathrm{N}\right.$, $79.09^{\circ} \mathrm{W}$ ) of the site of the Duke University FACE (Free Air CO2 Enrichment) Study. More specific details can be found in Katul et al. (1999). The study began on 7 July and ended on 27 July 2003. The gas phase measurement instrumentation was situated in a mobile trailer next to a $24 \mathrm{~m}$ sampling tower (situated in FACE ring \#6, a control ring with no canopy $\mathrm{CO}_{2}$ fumigation). Above canopy air, drawn from $24 \mathrm{~m}$ through a common $30 \mathrm{~m}$ (O.D.3/8") Teflon line using a rotary pump, supplied two Proton-transfer-reaction mass spectrometers (PTR-MS) (Lindinger et al., 1998) with a delay time of $\sim 5 \mathrm{~s}$. In addition, one chemiluminescense isoprene sensor (FIS) (Guenther and Hills, 1998) was deployed on the tower. All VOC instruments were deployed for measuring fluxes using either the eddy correlation or relaxed eddy accumulation method as described by Baker et al. $(2005)^{1}$. In addition, one of the PTR-MS instruments was deployed for within-canopy gradient measurements on 3 days of the study (17, 18 and 23 July). Micrometeorological measurements at ring 6 included turbulence measurements at 4 heights using the following sonic anemometers: RM Young 81000 (R. M. Young Company, USA) (16 m above ground) and ATI K-probe (Applied Technologies, USA) (2, 8 and $26 \mathrm{~m}$ above ground). Meteorological data (UV radiation, air temperature, precipitation, net radiation, 2-D winds) were collected during the whole campaign on top of the tower using a weather station (Vantage Pro2, Davis Instruments Corp., USA). Photolysis rates were measured on top of the tower and within the canopy at ring 6 using a UV-B Biometer (Model 501, Solar Light Co., USA) and filter radiometers (Metcon Inc., USA). PAR was measured using quantum sensors (Model LI-190SA, Li-Cor Inc., USA).

\subsection{PTRMS}

The PTRMS instrument has been described in detail elsewhere (Lindinger et al., 1998). Specifics on disjunct eddy covariance (DEC) measurements with PTR-MS can be found in Karl et al. (2002b, 2004) and for a detailed evaluation of the instrument we refer the reader to de Gouw et al. (2003a). The instrument was operated at $119 \mathrm{Td}$ at 2 mbar drift pressure. The transmission of the quadrupole mass spectrometer was checked by spiking pure compounds up to $178 \mathrm{amu}$ into the instrument and comparing the ratio of primary to product ions. Above 130 amu we observed a $30 \%$ decrease in transmission compared to the $70-120 \mathrm{amu}$ range. The detection limit based on a reaction rate constant of $2 \times 10^{-9} \mathrm{~cm}^{3} / \mathrm{s}, 10 \mathrm{~s}$ integration time and 1 count per second background noise was on the order of $5 \mathrm{ppt}$. The quantification of VOCs was based on gravimetrically prepared calibration standards with an estimated uncertainty of approximately $\pm 20 \%$. For those species for which no calibration standard was available, we calculated concentrations using the collisional rate constant, which is typically within $30 \%$ of the measured rate constant. Reference measurements for determining the instrument background were taken through a catalytic converter (platinum wool held at $430^{\circ} \mathrm{C}$ ) and were performed every

\footnotetext{
${ }^{1}$ Baker, B., Jardine, K., Mielke, L., Arnts, R. R., and Karl, T.: Above canopy flux measurements of biogenic VOCs during the 2003 CELTIC experiment at Duke Forest North Carolina, in preparation, 2005.
} 
$30 \mathrm{~min}$ to $2 \mathrm{~h}$. A detailed description of VOC eddy covariance (EC) (Guenther and Hills, 1998) and relaxed eddy accumulation measurements during CELTIC will be presented elsewhere (Baker et al., 2005 ${ }^{1}$ ).

\subsection{Gradient methodology}

A VOC gradient system similar to that described by Karl et al. (2004) was deployed during the CELTIC study. Air was pulled through a $30 \mathrm{~m}$ teflon line (1/4" O.D.) from the top of the sampling tower at a high flow rate $(\sim 0.3 \mathrm{l} / \mathrm{s})$, reducing the pressure inside the line to $400 \mathrm{mbar}$ in order to avoid water condensation, minimize memory effects and assure a fast response time. The overall delay time was $\sim 6 \mathrm{~s}$, measured by introducing an isoprene and acetone pulse at the top of the tower. The gradient sampling inlet line was attached to a pulley controlled by an automated winch, and canopy air was sampled continuously from the ground to $24 \mathrm{~m}$ height. The canopy line moved at a constant speed of $0.2 \mathrm{~m} / \mathrm{s}$ resulting in a complete profile about every $2 \mathrm{~min}$.

Source/sink profiles were computed according to,

$\boldsymbol{C}-C_{\text {ref }}=\stackrel{\leftrightarrow}{D} \cdot S$

with $\mathrm{C}$ (concentration vector), $\mathrm{C}_{\text {ref }}$ (concentration at reference height $24 \mathrm{~m}$ ), D (dispersion matrix) and $\mathrm{S}$ (source/sink vector). Parameterization of the dispersion matrix (21 concentration layers and 5 source/sink layers) was based on measured turbulent profiles and estimated Lagrangian timescales as described by Karl et al. (2004). For more detailed information on inverse Lagrangian modeling we refer the reader to Raupach (1989).

\subsection{Footprint calculation}

In order to estimate the flux footprint during day- and nighttime conditions we used a random walk model similar to that described by Baldocchi (1997) and Strong et al. (2004), parameterized with turbulence measurements made during the CELTIC study.

The random walk model was parameterized according to the random forcing term $(\mathrm{dw})$ for the one-dimensional case according to the Fokker-Planck equation (e.g. Eq. 4 in Baldocchi, 1997):

$\mathrm{dw}=\left(-\frac{w_{L}}{T_{L}}+\frac{1}{2}\left[1+\frac{w_{L}^{2}}{\sigma_{w}^{2}}\right] \frac{\partial \sigma_{w}^{2}}{\partial z}\right) \mathrm{dt}+\sqrt{\frac{2 \sigma_{w}^{2}}{T_{L}}} \mathrm{dr}$,

with $\mathrm{w}_{L}$ (Lagrangian vertical velocity), $\mathrm{T}_{L}$ (Lagrangian timescale), $\sigma_{w}$ (standard deviation of vertical wind component), dr (random forcing).

The trajectories for 5000 particles were released at 4 levels (25\%, 50\%, $75 \%$ and $100 \%$ of canopy) and computed for typical day and nighttime conditions. The mean residence time and horizontal distance traveled by the ensemble mean was used to assess the footprint in each layer and over the whole canopy (sum over 4 levels).
During daytime the mean horizontal distance traveled by an air mass was sufficiently short $(\sim 130-150 \mathrm{~m})$ that the measured VOC concentration in the canopy was dominated by emissions from the pine plantation. The surrounding oak forest had only a slight influence. During the night the prevalent wind direction originated from 300 degrees. The plantation extended $800 \mathrm{~m}$ in this upwind direction; compared to the average total distance traveled by the sampled air mass $(\sim 620-650 \mathrm{~m})$, this was sufficient to ensure that the sampled air originated within the plantation.

\section{Results and discussion}

\subsection{Leaf level measurements}

Leaf level measurements with potted plants performed in the NCAR laboratory were used to examine the processes controlling canopy scale exchanges.

\subsubsection{Methanol and acetone}

Over the examined concentration range $(0-12 \mathrm{ppb})$ both methanol and acetone were predominantly emitted from both young (younger than approx. 2 months) and mature (older than approx. 6 months) loblolly pine needles; emissions of both compounds exhibited an exponential temperature dependence between 20 and $40^{\circ} \mathrm{C}$. Table 1 summarizes the results for loblolly pine (4 leaf enclosure experiments using 4 different sets of needles from the same tree, each lasting for 3-4 days) and compares leaf level and eddy covariance measurements. Based on a measured leaf area index in the plantation of $2.8 \mathrm{~m}^{2}$ leaf $\mathrm{m}^{-2}$ ground (Stroud et al., 2005) and a leaf mass per area (LMA) of $230 \mathrm{~g} \mathrm{~m}^{-2}$ (Geron et al., 2000) for loblolly pine the average emission rates (164 and $144 \mathrm{pg} \mathrm{g}^{-1} \mathrm{~s}^{-1}$ for methanol and acetone, respectively) measured at standard conditions $\left(30^{\circ} \mathrm{C}, \sim 1000 \mu \mathrm{mol} \mathrm{m}^{-2} \mathrm{~s}^{-1}\right.$ PAR) compare well with results from the eddy covariance measurements. This comparison also supports findings from our gradient measurements that show a strong correlation between methanol and acetone emissions and the loblolly pine leaf area index. A set of leaf level measurements with sweetgum (Liquidambar styraciflua) (Table 2) indicate that substantial amounts of methanol can be emitted from young leaves (i.e., 20 times higher emission compared to a more mature leaf) and that acetone is emitted from both young and mature leaves. These observations of enhanced methanol production in young leaves support findings from previous studies (Fall and Benson, 1996). However, due to lower biomass density (LAI: $30 \%$ of total, LMA: $50 \mathrm{~g} \mathrm{~m}^{-2}$ ) and more shading in the understory the contribution of sweetgum to observed above canopy fluxes at Duke is small. In fact, canopy scale gradient measurements (next section) suggest that the portion of the canopy associated with most of the sweetgum biomass acts as a sink for both methanol and acetone. 
Table 1. Temperature dependent methanol and acetone emissions obtained for Loblolly pine (Pinus taeda); listed are the emission rate from disjunct eddy covariance (DEC) measurements and emission rates scaled up from leaf level measurements at $303 \mathrm{~K}$. Leaf level emission rates are normalized by dry weight in gram (e.g. $\left.\mathrm{g} \mathrm{g}^{-1}\right)$.

\begin{tabular}{|c|c|c|c|c|c|}
\hline & $\begin{array}{l}\mathrm{E}_{303} \mathrm{DEC}^{(\mathrm{a})} \\
\left(\mathrm{ng} \mathrm{m}^{-2} \mathrm{~s}^{-1}\right)\end{array}$ & $\begin{array}{r}\mathrm{E}_{303} \\
\left(\mathrm{ng} \mathrm{m}^{-2} \mathrm{~s}^{-1}\right)\end{array}$ & $\begin{array}{l}\operatorname{eaf}^{(a)} \\
\left(n g g^{-1} s^{-1}\right)\end{array}$ & $\begin{array}{c}\mathrm{b}_{e c}^{(\mathrm{a})} \\
\left(\mathrm{K}^{-1}\right)\end{array}$ & $\begin{array}{c}\mathrm{b}_{L}^{(\mathrm{a})} \\
\left(\mathrm{K}^{-1}\right)\end{array}$ \\
\hline Methanol & $101 \pm 33$ & $118 \pm 32$ & $6.0 \pm 1.2$ & $0.16 \pm 0.03$ & $0.12 \pm 0.02$ \\
\hline Acetone & $107 \pm 34$ & $104 \pm 32$ & $2.1 \pm 0.4$ & $0.08 \pm 0.01$ & $0.09 \pm 0.01$ \\
\hline
\end{tabular}

(a) fitted according to $\mathrm{E}_{303} \times \exp (\mathrm{b} \times(\mathrm{T}(\mathrm{K})-303)){ }^{\text {(b) }}$ converted from dry weight emission rate using a LAI of $2.8 \mathrm{~m}^{2} \mathrm{~m}^{-2}$ and a LMA of $230 \mathrm{~g} \mathrm{~m}^{-2}$

Table 2. Leaf Level measurements of methanol, acetone and acetaldehyde with sweetgum (Liquidambar styraciflua): E (methanol and acetone emission for a mature and young leaf at $28^{\circ} \mathrm{C}$ and $27^{\circ} \mathrm{C}$, respectively), Slope (inferred from the compensation point regression analysis), $\mathrm{E}_{0}$ (zero intercept inferred from regression analysis: exchange rate at 0 ppb concentration in incoming air) and $\mathrm{CP}$ (compensation point). Leaf level exchange rates are normalized by dry weight in gram (e.g. $\mathrm{g} \mathrm{g}^{-1}$ ).

\begin{tabular}{llccc}
\hline & & Methanol & Acetone & Acetaldehyde \\
\hline Mature leaf & $\mathrm{E} \mathrm{@} 28^{\circ} \mathrm{C}\left(\mathrm{pg}^{-1} \mathrm{~g}^{-1} \mathrm{~s}^{-1}\right)$ & $222 \pm 67$ & $278 \pm 83$ & - \\
& Slope $\left(\mathrm{pg} \mathrm{g}^{-1} \mathrm{~s}^{-1} \mathrm{ppb}^{-1}\right)$ & - & - & $-21.4 \pm 5.3$ \\
& $\mathrm{E}_{0}\left(\mathrm{pg}^{-1} \mathrm{~g}^{-1} \mathrm{~s}^{-1}\right)$ & - & - & $81 \pm 19$ \\
& $\mathrm{CP}(\mathrm{ppb})$ & - & - & $3.8 \pm 1.1$ \\
Young leaf & $\mathrm{E} \mathrm{@} 27^{\circ} \mathrm{C}\left(\mathrm{ng}^{-1} \mathrm{~g}^{-1} \mathrm{~s}^{-1}\right)$ & $4.4 \pm 1.4$ & $0.4 \pm 0.1$ & - \\
& $\mathrm{Slope}\left(\mathrm{pg} \mathrm{g}^{-1} \mathrm{~s}^{-1} \mathrm{ppb}^{-1}\right)$ & - & - & $-56.1 \pm 11$ \\
& $\mathrm{E} 0\left(\mathrm{pg} \mathrm{gg}^{-1} \mathrm{~s}^{-1}\right)$ & - & - & 0 \\
& $\mathrm{CP}(\mathrm{ppb})$ & - & - & 0 \\
\hline
\end{tabular}

\subsubsection{Acetaldehyde}

In order to determine the exchange pattern of acetaldehyde we performed detailed compensation point measurements on needles of Pinus taeda, the results of which are listed in Table 3. As an example, Fig. 1 illustrates the exchange of acetaldehyde plotted versus the concentration of outgoing air for young (left panels) and mature needles (right panels) before (top panels) and after (bottom panels) fumigation with $120 \mathrm{ppb}$ ozone. We selected periods when stomatal conductance did not change significantly and the temperature fluctuation inside the cuvette was less than $1^{\circ} \mathrm{C}$. For young needles, the exchange of acetaldehyde showed an average daily compensation point of $7.4 \mathrm{ppb}$. The range of compensation points observed for mature needles ranged between 3.7 and $8.5 \mathrm{ppb}$ (Table 3). This is comparable to values $(6.2 \mathrm{ppb}) \mathrm{re}-$ ported by Cojocariu et al. (2004) for Norway Spruce (Picea abies). Maximum uptake was typically observed in the afternoon and evening (15:00-22:00). While acetaldehyde bursts were observed after all rapid light/dark transitions, no significant emission of compounds related to wounding (e.g. hexenals) were present during these transitional periods.

Following several days of measurements using ozone free air, the same needles were fumigated with $100-150 \mathrm{ppb}$ ozone for $2 \mathrm{~h}$. An increase of acetaldehyde emissions dur- ing ozone exposure was observed. However it was not possible to quantify this increase due to a varying background of acetaldehyde triggered by the addition of ozone. After ozone treatment the VOC emissions declined rapidly. During the days following ozone fumigation we observed decreased exchange rates of acetaldehyde. With the exception of young needles, the post-fumigation compensation point returned close to the original value (suggesting no change in the total enzyme amount); however the slope (enzyme activity) typically changed to half of the original level. A recent study investigated the effect of elevated ozone concentrations on acetaldehyde emissions from beech (Fagus sylvatica) (Cojocariu et al., 2005). A significant increase in the acetaldehyde exchange rates was observed at $120 \mathrm{ppb}$ ozone, similar to results obtained during this study; however, it is not clear to what extent earlier results were masked by artifact formation of acetaldehyde as observed during the present study. Nevertheless our experiments show that even though no physiologically significant changes were obvious, the exchange rates of acetaldehyde were systematically lower on the days following $2 \mathrm{~h}$ of ozone fumigation. This argues that damage to enzymes responsible for acetaldehyde metabolism might have already occurred at ozone concentrations in the $100-150 \mathrm{ppb}$ range. 
Table 3. Leaf level compensation point measurements of acetaldehyde for Loblolly Pine (Pinus taeda). Compensation point measurements with 4 sets of needles are summarized as follows (lines 1-7): Slope (inferred from the compensation point regression analysis), $\mathrm{E}_{0 c}$ (zero intercept inferred from regression analysis: emission at 0 ppbv concentration in incoming air) and CP (compensation point). Net photosynthesis rates (Net PS rate per gram dry weight) are summarized in the last column. The temperature dependence is summarized in lines 9 and 10: $\mathrm{E}_{0 c 303}$ (zero intercept inferred from regression analysis at $303 \mathrm{~K}$ : emission at 0 ppbv concentration in incoming air), $\mathrm{b}_{0}$ (exponential temperature dependence of zero intercept), $\mathrm{CP}_{303}$ (compensation point at $303 \mathrm{~K}$ ) and $\mathrm{b}_{c p}$ (exponential temperature dependence of the compensation point). Leaf level emission rates are normalized by dry weight in gram (e.g. $\mathrm{g} \mathrm{g}^{-1}$ ).

\begin{tabular}{lcccc}
\hline & Slope $\left(\mathrm{pg} \mathrm{g}^{-1} \mathrm{~s}^{-1} \mathrm{ppb}^{-1}\right)$ & $\mathrm{E}_{0 c}\left(\mathrm{pg} \mathrm{g}^{-1} \mathrm{~s}^{-1}\right)$ & $\mathrm{CP}(\mathrm{ppb})$ & Net PS rate $\left(\mu \mathrm{molg}^{-1} \mathrm{~h}^{-1}\right)$ \\
\hline Set 1 before O3 (mature) & $-3.1 \pm 0.3$ & $11.1 \pm 1.1$ & $3.7 \pm 0.6$ & $147 \pm 7$ \\
Set 1 1 day after O3 & $-1.7 \pm 0.1$ & $5.6 \pm 0.6$ & $3.5 \pm 0.5$ & $138 \pm 6$ \\
Set 2 before O3 (mature) & $-10.8 \pm 0.8$ & $91.7 \pm 2.8$ & $8.5 \pm 1.3$ & $203 \pm 14$ \\
Set 2 1 day after O3 & $-5.5 \pm 0.3$ & $50 \pm 2.8$ & $8.0 \pm 1.3$ & $203 \pm 10$ \\
Set 3 before O3 (young) & $-3.5 \pm 0.3$ & $25.7 \pm 5.6$ & $7.4 \pm 2.5$ & - \\
Set 3 1 day after O3 & $-4.3 \pm 0.6$ & $3.3 \pm 0.1$ & $0.8 \pm 0.4$ & - \\
Temperature dependence & $\mathrm{E}_{0 c 303}^{(\mathrm{a})}\left(\mathrm{pg}^{-1} \mathrm{~g}^{-1} \mathrm{~s}^{-1}\right)$ & $\mathrm{b}_{0}^{(\mathrm{a})}\left(\mathrm{K}^{-1}\right)$ & $\mathrm{CP}_{303}^{(\mathrm{b})}(\mathrm{ppb})$ & $\mathrm{b}_{c p}^{(\mathrm{b})}\left(\mathrm{K}^{-1}\right)$ \\
Set 4 (mature) & $26.8 \pm 2.8$ & $0.10 \pm 0.005$ & $4.3 \pm 0.5$ & $0.11 \pm 0.006$ \\
\hline
\end{tabular}

(a) fitted according to $\mathrm{E}_{0 c 303} \times \exp \left(\mathrm{b}_{0} \times(\mathrm{T}(\mathrm{K})-303)\right) ; \mathrm{R}^{2}=0.98$. (b) fitted according to $\mathrm{CP}_{303} \times \exp \left(\mathrm{b}_{c p} \times(\mathrm{T}(\mathrm{K})-303)\right) ; \mathrm{R}^{2}=0.99$.
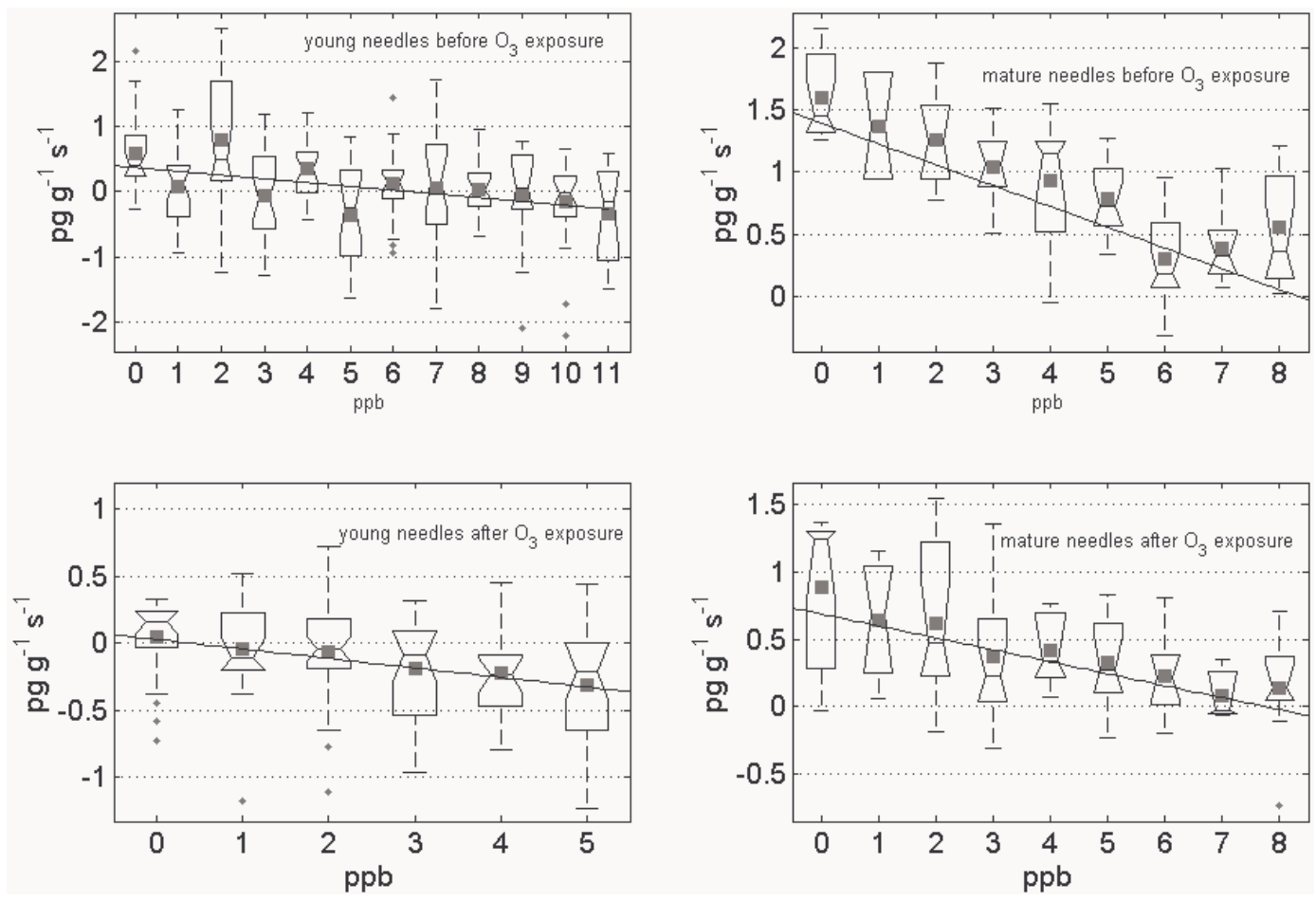

Fig. 1. Example of compensation point measurements for acetaldehyde with Loblolly pine (Pinus taeda) using young needles before (upper left) and after $120 \mathrm{ppb}$ ozone exposure (lower left) and mature needles before (upper right) and after 120 ppb ozone exposure (lower right). Exchange rates $\left(\mathrm{pg} \mathrm{g}^{-1} \mathrm{~s}^{-1}\right)$ are plotted vs outgoing air concentration in ppb. Leaf level exchange rates are normalized by dry weight in gram (e.g. $\mathrm{g} \mathrm{g}^{-1}$ ). Symbols in statistical plot are defined as following: gray square symbol: mean; center horizontal line: median: upper and lower horizontal lines: upper and lower quartile; whiskers: extent of the rest of the data.

Acetaldehyde emissions changed with temperature reflected by an exponentially increasing compensation point (Table 3). Figure 2 shows a plot of the compensation point versus temperature for mature loblolly needles. The tem- perature dependence points toward competing enzyme reactions similar as observed for $\mathrm{CO}_{2}$ uptake in plants. Multiple competing enzyme reactions involved with acetaldehyde metabolisms in plants have been proposed in previous studies 
(Kreuzwieser et al., 2000; Karl et al., 2002a; Graus et al., 2004). The production rate per ppb of acetaldehyde (slope in Fig. 1), which corresponds to the total enzyme activity, did not change drastically at different temperatures.

An emission rate dependent on ambient acetaldehyde concentration has also been observed above different ecosystems (Cojocariu et al., 2004; Rottenberger et al., 2004) and implies that the temperature dependence of canopy scale VOC fluxes should only be applied to a temperature range that was measured during a particular study. Extrapolation to higher temperatures would need to include the effect of a compensation point and other factors such as transpiration rates. Otherwise the overall emissions would at best be guesstimates. In these cases a relationship between VOC fluxes with sensible or latent heat fluxes might be more accurate for upscaling purposes as it includes physiologically driven variables (such as transpiration). Inappropriate upscaling of biogenic OVOC emissions by Singh et al. (2004) could explain part of the variability between different studies summarized by these authors.

\subsubsection{Other oxygenated VOCs observed during ozone fu- migation}

OVOC appearing in air exiting the leaf enclosure during ozone fumigation could represent either direct leaf emissions or oxidation products arising from ozone reacting with either leaf surfaces or with other reactive gas-phase emissions, such as mono- or sesquiterpenes. Two experimental protocols were used distinguish between primary (i.e., direct OVOC emissions or the OVOC products of leaf surface-ozone reactions) and secondary OVOC production (i.e., the OVOC products of ozone reactions with gas-phase emissions). In the first case, ozone was added immediately before the plant cuvette. The mixing time was measured to be on the order of 25-30 s. In the second case ozone was added to the air stream exiting the plant cuvette and passed through a second glass mixing vessel, sized so that the total residence time (25-30s) roughly matched the residence time in the plant cuvette. In the second case, in which the needles are not exposed directly to ozone, any additional OVOC observed exiting the second mixing vessel must be secondary in nature, i.e., the product of reactions between ozone and VOC emissions from the needles. By subtraction, the nature and amount of OVOC arising from either direct emission or ozone-needles interactions, i.e., primary OVOC, can be estimated. Empty cuvette blanks showed that artifact formation on glass surfaces during the addition of ozone were minimal. While an ozone induced increase of terpene emissions cannot be excluded on longer timescales (hours), our measurements of post-exposure emissions immediately after fumigation indicated that the total amount of terpenes and sesquiterpenes did not change significantly within the time scale of minutes (e.g. 15-40).

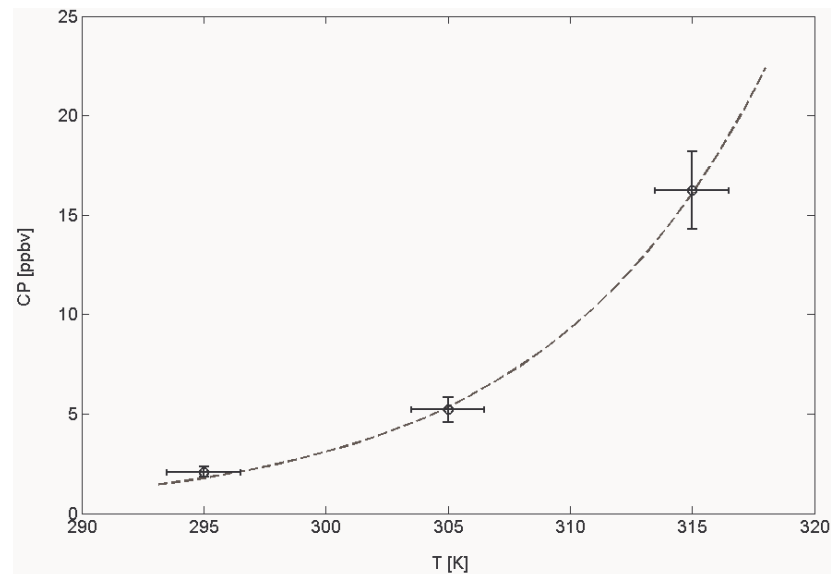

Fig. 2. Compensation point (CP) plotted vs temperature. The dashed line shows a fit according to $\mathrm{CP}_{303} \times \exp \left(\mathrm{b}_{c p} \times(\mathrm{T}\right.$ $(\mathrm{K})-303)) ; \mathrm{R}^{2}=0.99$.

The results of one fumigation experiment are shown in Fig. 3, which shows the relative (upper panel) and absolute (lower panel) concentration difference of mass spectra observed by the PTR-MS instrument between the no ozone fumigation base case and the two fumigation experiments in which $200 \mathrm{ppb} \mathrm{O}_{3}$ was added either before or after the leaf enclosure ( $\sim 15 \mathrm{~min}$ exposure time in both cases). For simplicity, only odd $\mathrm{m} / \mathrm{z}$ ratios above $100 \mathrm{amu}$ are shown. Positive values indicate reactive losses. For example more than $80 \%$ (relative ratio $>0.8)$ of the reactive sesquiterpenes $(\mathrm{m} / \mathrm{z}$ 205) (dominated by $\beta$-caryophyllene as inferred from parallel GC-FID measurements) were oxidized during the brief mixing time within the chamber, regardless of whether ozone was added before or after the chamber. Negative values represent the production of compounds during the addition of ozone. In particular ions corresponding to a series of $\mathrm{C}_{9}$ $\mathrm{C}_{13}$ aldehydes and unsaturated alcohols $(\mathrm{m} / \mathrm{z} 125$ and 143 , $\mathrm{m} / \mathrm{z} 139$ and 157, m/z 153 and 171, m/z 167 and 185 and $\mathrm{m} / \mathrm{z} 181$ and 199) and compounds exhibiting ions 2 amus higher (e.g. saturated alcohols) were dramatically enhanced when ozone was added before the plant chamber (Fig. 3, dark bars). Many of these aldehydes and alcohols are known to be linked to wounding and plant damage through lipoxygenase type reactions that are also responsible for the so-called "green odor" of plants (Hatanaka, 1996; Fall, 1999; Wildt et al., 2003). Some others may correspond to compounds that have been identified during ozonolysis at vegetation surfaces (e.g. m/z 127: 6-methyl-5-hepten-2-one and m/z 195: geranyl acetone) (Fruekilde et al., 1998). When ozone was added after the plant chamber, the biggest changes were observed in ions exhibiting m/z 111 and 129, and m/z 127 and 145 ; these must result from secondary gas phase formation via oxidation of reactive plant emissions (e.g., terpenoids). These ions most likely correspond to ketones, ketoaldehdyes and aldehydes that have tentatively been identified from the oxidation of terpenoids (Calogirou et al., 1999). 


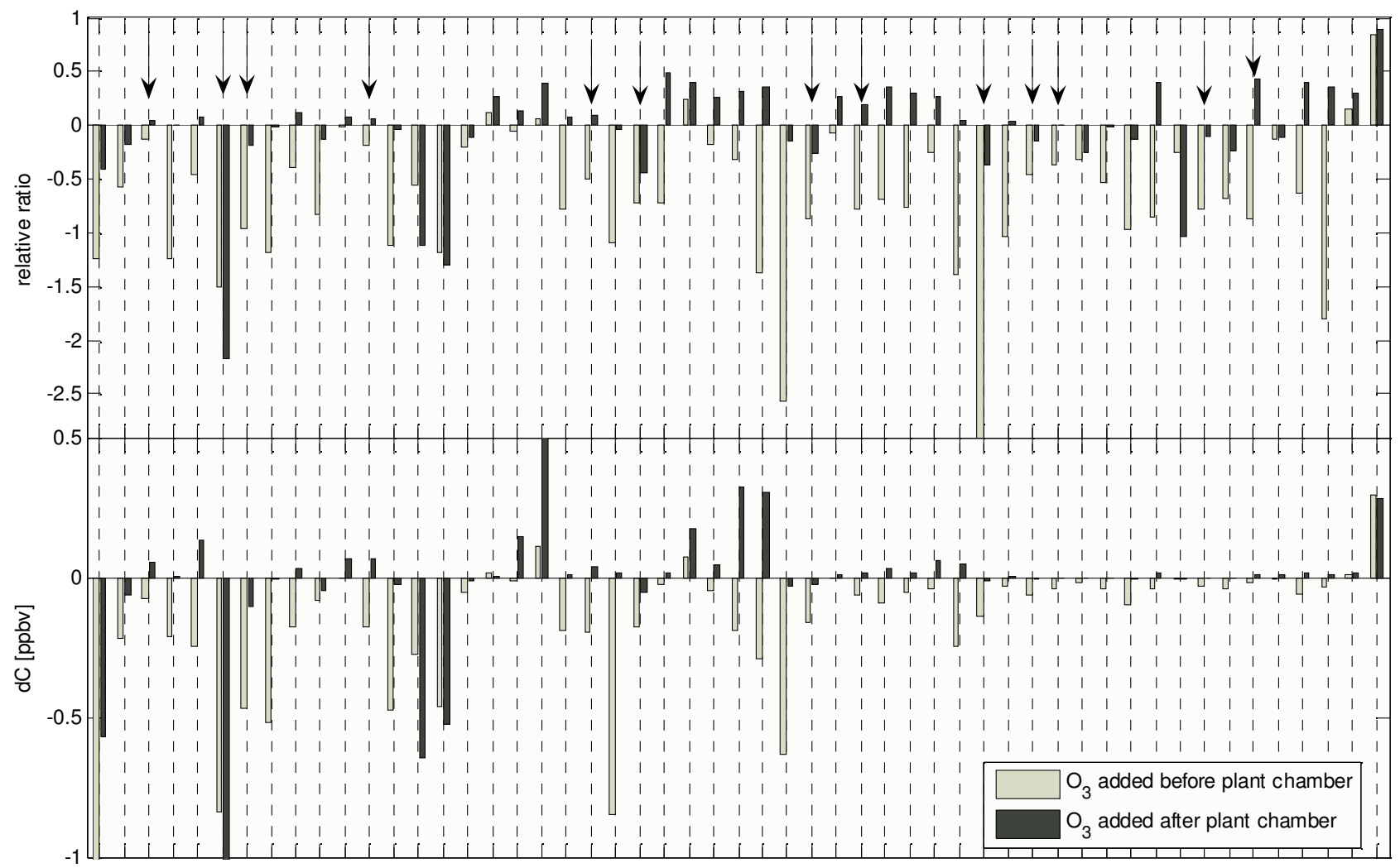

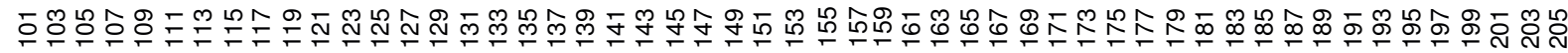

$\mathrm{m} / \mathrm{z}$

Fig. 3. PTR-MS mass scans during ozone fumigation. For simplicity only odd $\mathrm{m} / \mathrm{z}$ ratios are plotted. Upper panel: The Y-axis depicts the relative concentration difference before minus after the addition of $200 \mathrm{ppb}$ ozone $\left(\mathrm{C}_{\mathrm{noO} 3}-\mathrm{C}_{O 3}\right) / \mathrm{C}_{\text {noO3 }}$. Positive values indicate reactive losses (positive if the concentration without ozone was higher) and negative values indicate production induced by ozone. By definition the upper limit is 1 (100\% is lost after the addition of ozone). Arrows indicate $\mathrm{m} / \mathrm{z}$ ratios recently assigned to secondary oxygenated compounds (Holzinger et al., 2004). Lower panel: The Y-axis shows the absolute concentration difference (dC) before minus after the addition of 200 ppbv ozone.

Of particular interest are those masses which increased during ozone exposure, but which exhibited marked differences depending on whether the ozone was added before or after the leaf enclosure. If the increase in a given mass is the result of reactions between ozone and primary leaf emissions, the enhancement should be independent of where the ozone addition takes place. However, if the enhancement is the result of interactions between ozone and the plant itself, enhancement should be greater when ozone is added before the plant chamber.

The timescales of mixing in these laboratory experiments $(\sim 30 \mathrm{~s})$ are somewhat lower than typical turbulent time scales $(60-120 \mathrm{~s})$ in a $6 \mathrm{~m}$ tall canopy; however, they are within the range of chemical lifetimes of very reactive terpenes. The arrows in Fig. 3 indicate compounds that have previously been assigned to secondary species formed due to reactions of ozone with very reactive compounds emitted from pines (Holzinger et al., 2004). Our measurements imply that, with the exceptions of $\mathrm{m} / \mathrm{z} 111,127,129,143$ and 145, the bulk of these compounds are likely the result of either direct reactions of ozone with plant surfaces or damaging effects of ozone inside the plant (comparison of negative ratios in Fig. 3).

Overall, 13 ozone addition experiments were conducted. We performed 5 (3) experiments on the same loblolly (ponderosa) pine tree using different branches for each experiment. Qualitatively similar results were obtained at 50$80 \mathrm{ppb}$ ozone concentrations. While results shown in Fig. 3 were obtained with loblolly pine, similar results (not shown) were found for needles of ponderosa pine (Pinus ponderosa).

\subsubsection{Ozone uptake measurements}

In order to determine what fraction of ozone is lost through stomata and what fraction reacts in the gasphase and on leaf surfaces a set of experiments was performed where the ozone 
Table 4. Temperature Dependence of VOC emissions during an ozone exposure experiment of $100 \mathrm{ppb}$ and oVOC emissions as a function of ozone flux. Fits were obtained from data shown in Figs. 5 and 6. Wound VOCs are defined as the sum of lipoxygenase products $\left(\mathrm{C}_{6}\right.$ leaf aldehydes and alcohols). Oxy VOCs are defined as the sum of all masses indicated by arrows in Fig. 3. MT is the sum of monoterpenes and SQT is the sum of sesquiterpenes (mostly beta-caryophellene). Experiment was performed on needles of Loblolly pine (Pinus taeda).

\begin{tabular}{ccccc}
\hline Temperature & Wound VOC & OXY VOC & MT & SQT \\
\hline $\mathrm{E}_{T 0}\left(\mathrm{pmol} \mathrm{g}^{-1} \mathrm{~s}^{-1}\right)^{(\mathrm{a})}$ & $8.6 \pm 0.2$ & $3.4 \pm 0.2$ & $4.6 \pm 0.3$ & $0.25 \pm 0.05$ \\
$\mathrm{~b}_{0}\left(\mathrm{~K}^{-1}\right)^{(\mathrm{a})}$ & $0.070 \pm 0.003$ & $0.082 \pm 0.004$ & $0.131 \pm 0.007$ & $0.155 \pm 0.019$ \\
Ozone & & & & - \\
$\mathrm{E}_{O 3}\left(\mathrm{pmol} \mathrm{g}^{-1} \mathrm{~s}^{-1}\right)^{(\mathrm{b})}$ & $7.9 \pm 1.0$ & $3.2 \pm 0.5$ & - & - \\
${\mathrm{a}\left(\mathrm{g} \mathrm{s} \mathrm{pmol}^{-1}\right)^{(\mathrm{b})}}^{0.047 \pm 0.02}$ & $0.05 \pm 0.02$ & - & - \\
\hline
\end{tabular}

(a) fitted according to $\mathrm{E}_{T 0} \times \exp \left(\mathrm{b}_{0} \times(\mathrm{T}(\mathrm{K})-303)\right){ }^{\text {(b) }}$ fitted according to $\mathrm{E}_{O 3} \times \mathrm{a} \times \mathrm{F}_{O 3} / \mathrm{sqrt}\left(1+\mathrm{a}^{2} \mathrm{~F}_{O 3}\right)$ ), with $\mathrm{F}_{O 3}$ being the ozone uptake

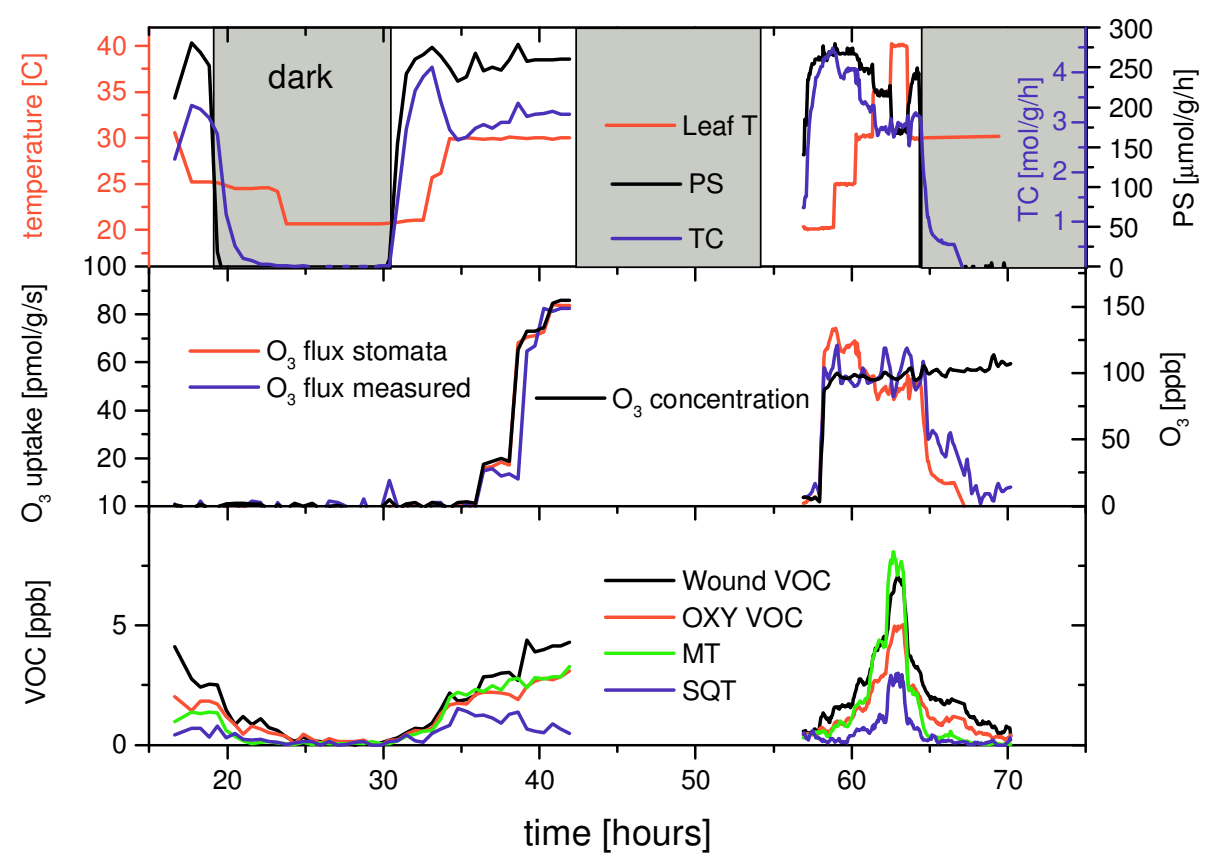

Fig. 4. Ozone fumigation of Loblolly Pine (Pinus Taeda). Top panel shows net photosynthesis rates (PS) in black, total conductance (TC) in blue and leaf temperature in red. Middle panel shows ozone flux calculated from total conductance data $\left(\mathrm{O}_{3}\right.$ flux stomata: red), ozone flux measured in differential mode $\left(\mathrm{O}_{3}\right.$ flux measured blue) and ozone concentration entering the cuvette (black). Lower panel shows $\mathrm{C}_{6}$ wound aldehydes (black), OXY VOCs (sum of all compounds indicated by arrows in Fig. 3 with the exception of m/z 111, m/z 127 and m/z 129 which are predominantly produced from gas phase reactions: red), monoterpenes (MT: green) and sesquiterpenes (SQT: blue).

difference between air entering and exiting the cuvette was measured. The top panel shows net photosynthesis rates (black), total conductance to water vapor (blue) and temperature (red). Gray shaded areas indicate dark periods. Assuming ozone and water vapor diffuse into the leaf along the same diffusion path, leaf conductance to ozone can be estimated by dividing conductance to water vapor by the ratio of their diffusivities in air (1.6). Assuming that ozone reacts immediately upon entering the leaf (i.e., ozone concentration within the leaf is zero) then the ozone flux into the leaf can be estimated as the product of leaf conductance to ozone times the ozone concentration surrounding the leaf. The mid- dle panel compares the ozone uptake flux calculated in this way (red) with a direct measurement of ozone uptake, determined by an ozone difference measurement (blue) between air entering and exiting the cuvette. Also shown is the ozone concentration entering the cuvette (black). Blank runs were used to characterize ozone destruction on wall surfaces of the cuvette, which were found to be small due to the short residence time. In this experiment most of the ozone loss can be explained by ozone uptake through stomata. Photosynthesis rates and stomatal conductance were not impacted significantly by this short term ozone exposure $\mathrm{CO}_{3}$ concentration range: $0-150 \mathrm{ppb}$, accumulated ozone threshold 


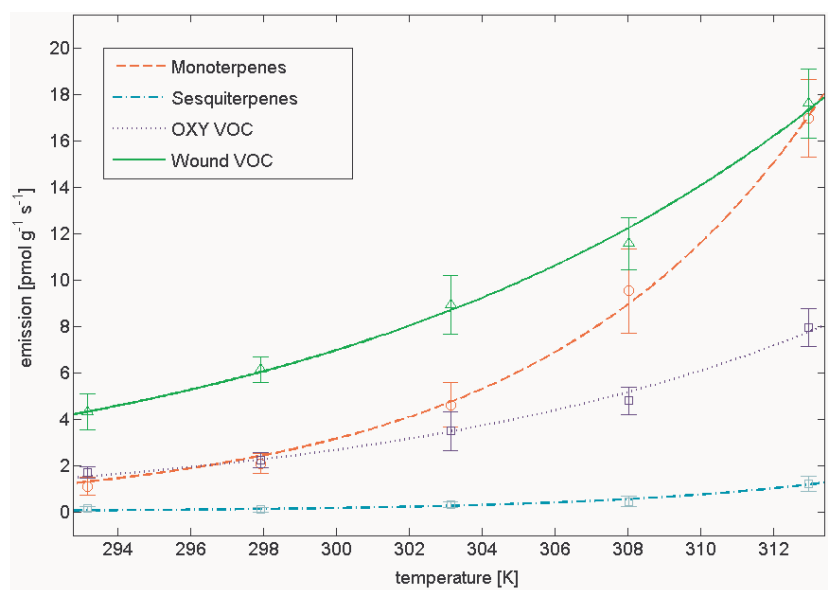

Fig. 5. Temperature dependence of VOC emissions at $100 \mathrm{ppb}$ Ozone entering the leaf cuvette for VOCs shown in Fig. 4. Corresponding fits are included in Table 4.

above $40 \mathrm{ppbv}$ (AOT 40): $15.6 \mathrm{ppb}$ ); temperature impacted photosynthesis rates and stomatal conductance to a much larger extent. Despite no clear physiological evidence of leaf damage, VOC emissions related to ozone damage were already triggered at these ozone concentrations. The lower panel in Fig. 4 shows the concentrations of monoterpenes and sesquiterpenes (corrected for lifetime, assuming mostly b-caryophellene) as well as the sum of $\mathrm{C}_{6}$ wound VOCs $(\mathrm{m} / \mathrm{z} \mathrm{143}, \mathrm{m} / \mathrm{z} \mathrm{101,} \mathrm{m} / \mathrm{z} 99, \mathrm{~m} / \mathrm{z} 83$ and monoterpene corrected residual on $\mathrm{m} / \mathrm{z} 81$ ) and OXY VOCs (sum of all compounds indicated by arrows in Fig. 3 with the exception of $\mathrm{m} / \mathrm{z} 111, \mathrm{~m} / \mathrm{z} 127$ and m/z 129 which are predominantly produced from gas phase reactions). Figure 5 shows a plot of VOC emissions versus leaf temperature from the same experiment. In general, all VOC emissions follow an exponentially increasing temperature trend under constant conditions ( $\mathrm{PAR}=740 \pm 18$ and $100 \mathrm{ppb} \mathrm{O}_{3}$ ), obeying the general exponential equation $\left(\mathrm{y}=\mathrm{E}_{\mathrm{T} 0} \times \exp \left(\mathrm{b}_{0}\left(\mathrm{~T}_{k}-303\right)\right)\right.$ where $\mathrm{E}_{\mathrm{T} 0}$ is the measured emission rate at $303 \mathrm{~K}$ and $\mathrm{T}_{k}$ is leaf temperature (K). Results are summarized in Table 4. The exponential $\mathrm{b}_{0}$ factor is similar for wound VOCs and oxygenated VOCs but is about a factor of two higher for mono- and sesquiterpenes. Assuming that very reactive terpenes (Holzinger et al., 2004) exhibit a temperature dependence similar to that of mono- and sesquiterpenes, this may indicate that the emission of many oxygenated VOCs might not be entirely linked to the emission of reactive terpenes, but could potentially be generated by ozone reacting with leaf constituents. Figure 5 shows a plot of VOC emission rates vs. rates of ozone loss, which in the present case was mostly the result of stomatal uptake. A fit to an equation (Table 4) similar to that used by Wildt et al. (2003) is used to relate the increase of VOC emissions to ozone uptake. At higher rates of ozone uptake, the VOC emissions saturate which suggests primary production of these compounds by the plant. If gas phase reactions

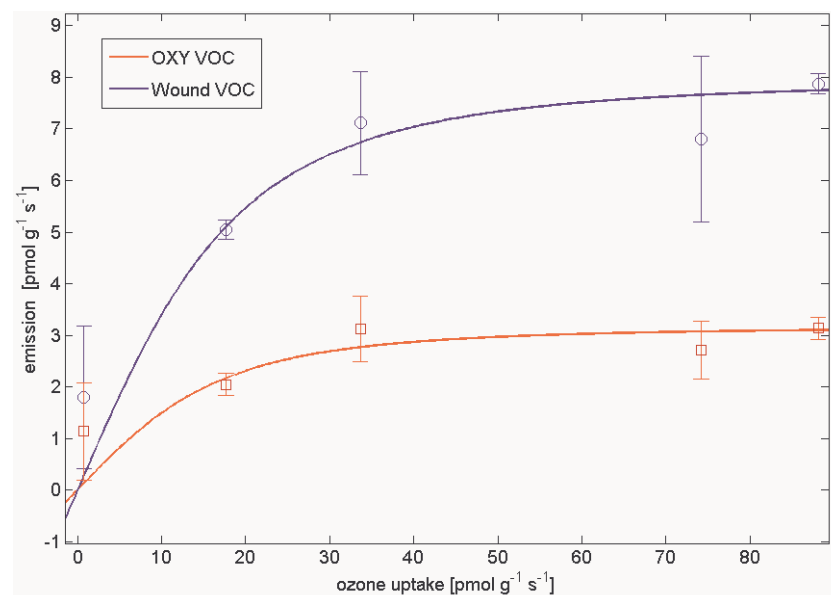

Fig. 6. VOC emission increase from baseline emissions as a function of ozone uptake measured at $30^{\circ} \mathrm{C}$. $\mathrm{C}_{6}$ wound aldehydes are plotted in blue circles and OXY VOCs (sum of all compounds indicated by arrows in Fig. 3 with the exception of m/z 111, m/z 127 and $\mathrm{m} / \mathrm{z} 129$ which are predominantly produced from gas phase reactions) are plotted in red square symbols. Corresponding fits are included in Table 4.

dominated, a linear increase would be expected. More measurements will be needed in the future to examine the effect of long term $\mathrm{O}_{3}$ exposure and variability on the production of these compounds.

\subsection{Canopy scale measurements}

\subsubsection{Eddy covariance measurements}

A more detailed analysis of VOC flux measurements will be presented elsewhere (Baker et al., 2005 ${ }^{1}$ ). Results obtained from eddy covariance measurements of methanol and acetone agreed within the variability of the gradient measurements (Table 5) during the day and generally showed a diurnal cycle. The emission of both compounds correlate with latent and sensible heat fluxes (Baker et al., 2005 ${ }^{1}$ ). Eddy covariance data for acetaldehyde are more ambiguous due to the complex exchange pattern of this compound and some instrumental problems associated with one PTR-MS instrument that was used for DEC measurements. The gradient data (next section) suggest acetaldehyde loss in the canopy and emission during certain transitional morning and evening hours.

\subsubsection{Gradient measurement}

Figure 7 depicts concentration profiles measured for methanol, acetone, acetaldehyde, acetic acid, MVK+MAC and $\mathrm{m} / \mathrm{z}$ 73. Using the PTR-MS instrument, ions observed at $\mathrm{m} / \mathrm{z} 73$ have tentatively been assigned to $\mathrm{C}_{4}$ and $\mathrm{C}_{3}$ carbonyls such as methyl ethyl ketone and methyl-glyoxal (de Gouw et al., 2003b). Under conditions of low collisional energies and 

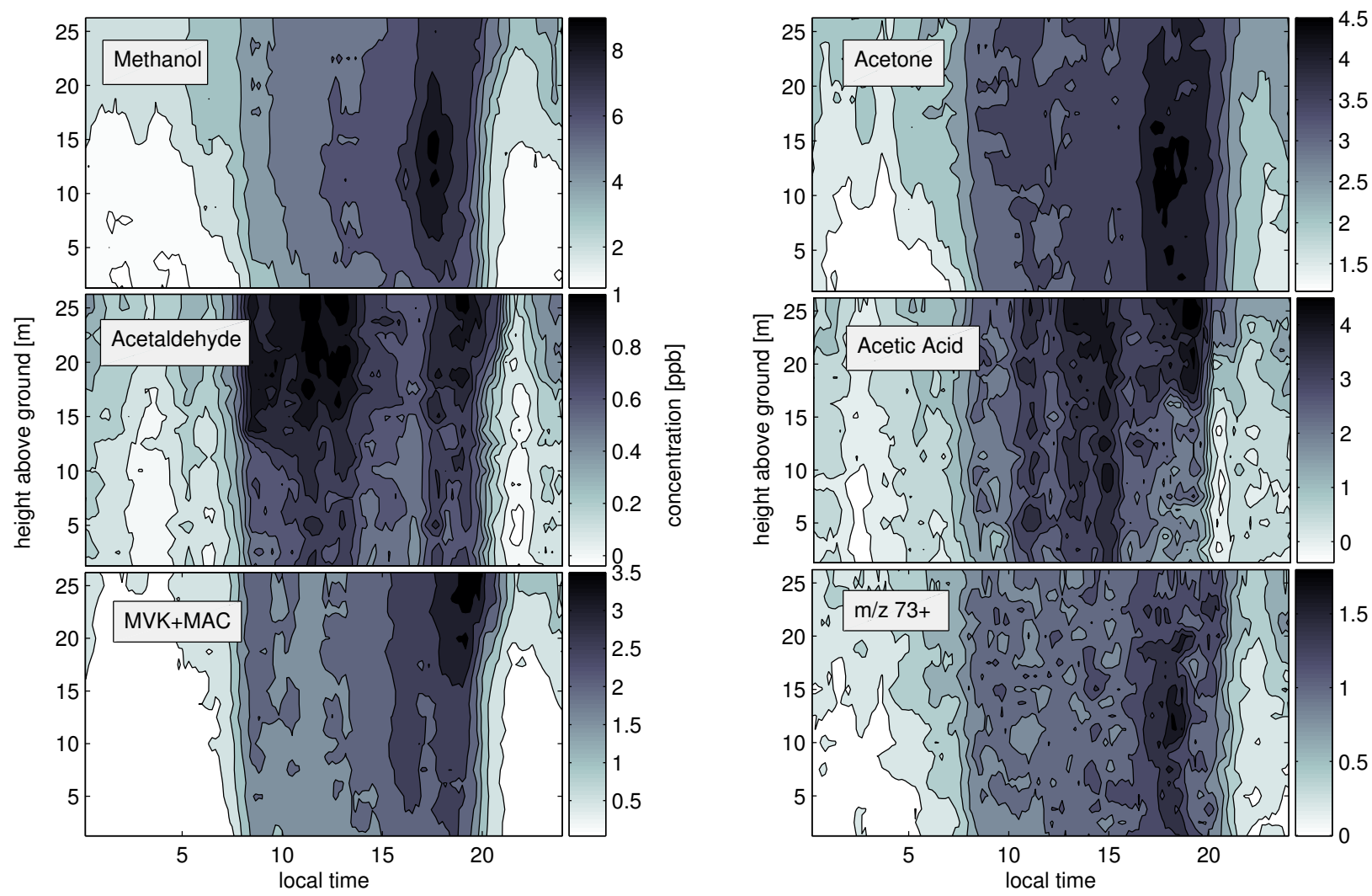

Fig. 7. Concentration gradients measured within the Duke Forest stand for methanol, acetone, acetaldehyde, acetic acid, MVK+MAC and $\mathrm{C}_{3}+\mathrm{C}_{4}$ carbonyls.

high humidity the third water cluster $\left(\left(\mathrm{H}_{2} \mathrm{O}\right)_{3} \mathrm{H}_{3} \mathrm{O}^{+}\right)$could also interfere at $\mathrm{m} / \mathrm{z} 73$. Reference measurements through a conditioned catalytical converter however can be used to characterize this interference, since water is not removed by the converter. Under the operating conditions used during the CELTIC study most of the water cluster was fragmented and we conclude that the abundance on $\mathrm{m} / \mathrm{z} 73$ was most likely caused by carbonyls. From these concentration gradients source and sink profiles are calculated according to Eq. (1) and expressed as an exchange velocity (ev), which we define as the flux $\left(\mathrm{F}_{c}\right)$ divided by the mean concentration (C) in each layer (ev:=Fc/C). Figure 8 shows a plot of these profiles as a function of height for mean daytime (10 to $17 \mathrm{~h}$ ) and nighttime conditions ( 22 to $5 \mathrm{~h}$ ). Negative values indicate uptake and positive values indicate emission. The nighttime inversion was assumed to lie between 12 and $15 \mathrm{~m}$ (canopy top). The reference height $\left(\mathrm{z}_{\text {ref }}\right)$ for the inverse calculation during night was averaged over this interval. Errors associated with these profiles were estimated to be on the order of $\pm 30 \%$, based on a comparison of different inverse schemes (Karl et al., 2004). Fluxes as well as average exchange velocities are summarized in Table 5. We define an average exchange velocity as the mean and a net exchange velocity as the integral over the whole canopy. The mean daytime flux obtained from the gradient method compares well to fluxes calculated from the eddy covariance method (Baker et al., $2005^{1}$ ). Results from both flux measurement methods are listed in Table 5.

\subsubsection{Methanol and acetone (Fig. 5 panels a and b)}

During the day, methanol is predominantly emitted from loblolly pine and mostly deposited in the lower part of the canopy and to the ground (Fig. 5, panels a and b). The mean daytime flux inferred from the ILT technique was $144 \mathrm{ng} \mathrm{m}^{-2} \mathrm{~s}^{-1}$ (mean temperature: $27.3^{\circ} \mathrm{C}$, mean radiation $\left.1466 \mu \mathrm{mol} \mathrm{m}^{-2} \mathrm{~s}^{-1} \mathrm{PAR}\right)$. Within the variability this agrees with results from the EC measurements of $89 \mathrm{ng} \mathrm{m}^{-2} \mathrm{~s}^{-1}$. Recent observations above a deciduous forest in Germany found similar methanol emissions on the order of $87 \mathrm{ng} \mathrm{m}^{-2} \mathrm{~s}^{-1}$ (Spirig et al., 2005). At night there is significant methanol uptake, similar to what was observed above a tropical ecosystem (Karl et al., 2004). The net exchange velocity (integral over the canopy height) was as high as $-0.96 \mathrm{~cm} / \mathrm{s}$ and was $\sim 33 \%$ of that estimated for a tropical rain forest $\left(-2.9 \mathrm{~cm} \mathrm{~s}^{-1}\right)$ in Costa Rica. The mean nighttime exchange velocity (ev) (Table 5 was $-0.30 \mathrm{~cm} \mathrm{~s}^{-1}$ ). The exchange velocity in the lowest layer (soil) during the day, which includes the forest floor, was $-0.14 \mathrm{~cm} \mathrm{~s}^{-1}$. For 


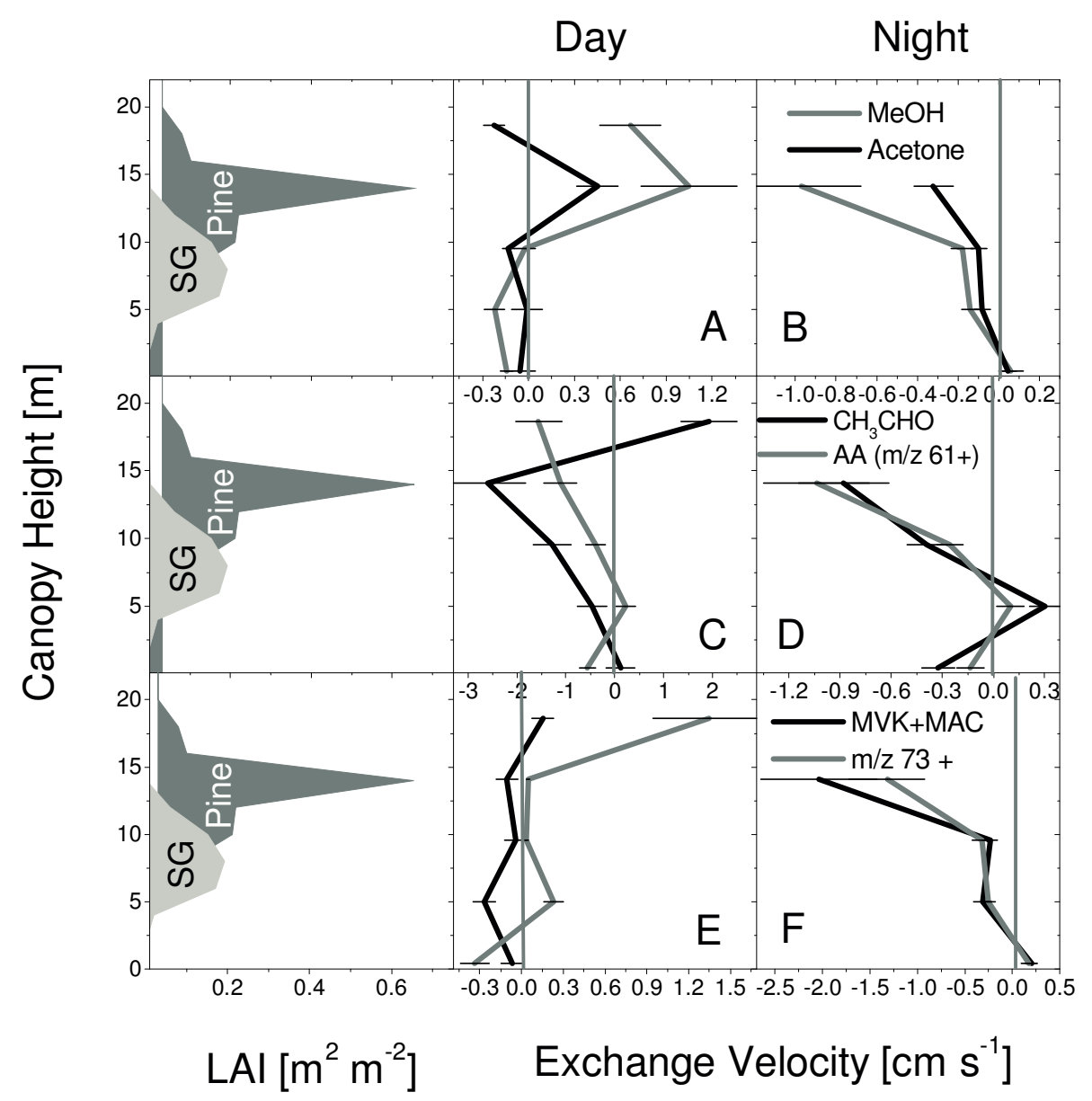

Fig. 8. Inverse source/sink profiles for mean day (10:00 to 17:00) and nighttime (22:00 to 05:00) conditions calculated for methanol (MeOH), acetone (A, B), acetaldehyde $\left(\mathrm{CH}_{3} \mathrm{CHO}\right)$, acetic acid (AA) $(\mathbf{C}, \mathbf{D}), \mathrm{MVK}+\mathrm{MAC}$ and $\mathrm{C}_{3} / \mathrm{C}_{4}$ carbonyls $\left(\mathrm{m} / \mathrm{z} 73^{+}\right)(\mathbf{E}, \mathbf{F})$. Left panels depict the leaf area index (LAI) for sweetgum (SG) (Liquidambar styraciflua) and loblolly pine (LP) (Pinus taeda) inferred from Stroud et al. (2005).

comparison the aerodynamic limit for nighttime deposition velocities was measured to be on the order of 1 to $2 \mathrm{~cm} \mathrm{~s}^{-1}$. The upper limit of the dry deposition velocity for methanol and acetone calculated according to Wesely (1989) would be on the order of $\sim 0.02 \mathrm{~cm} \mathrm{~s}^{-1}$. Air chemistry models which rely on this parameterization might therefore underestimate the effect of deposition. The acetone emission profile indicates that the loblolly pine stand was the main source, which was verified by plant enclosure measurements. During the night the exchange velocities suggest mostly deposition. The deposition is smaller than that of methanol, although still significant with a total net exchange velocity of $-0.46 \mathrm{~cm} \mathrm{~s}^{-1}$ and a mean nighttime exchange velocity of $-0.11 \mathrm{~cm} \mathrm{~s}^{-1}$ comparable to our results above a tropical rain forest.

Methanol is lost and the exchange of acetone is close to zero in the lower canopy during daytime, in contrast to leaf level measurements which demonstrated that methanol and acetone can potentially be emitted from sweetgum ( $L i q$ uidambar styraciflua). This indicates that the lower part of the canopy acts as a sink for methanol rather than a source of these compounds implying additional loss processes such as dry deposition. Understory species typically "see" less light and therefore transpiration rates and stomatal conductance were likely lower in the field resulting in lower emissions. The fact that the canopy acted as sink could be explained by a combination of small emission and dry deposition to the ground and other surfaces. It is interesting to note that the exchange rate of the more soluble/polar species methanol is significantly below 0 , while the acetone exchange is close to 0 .

Overall the magnitude of methanol (83-139 $\mathrm{ng} \mathrm{m}^{-2} \mathrm{~s}^{-1}$ ) and acetone emissions (31-103 $\mathrm{ng} \mathrm{m}^{-2} \mathrm{~s}^{-1}$ ) are comparable to those found in similar ecosystems. Schade and Goldstein (2001) for example reported typical daytime fluxes $\left(\mathrm{T}=25^{\circ} \mathrm{C}\right)$ of $\sim 1.2 \mu \mathrm{g} \mathrm{m}^{-2} \mathrm{~s}^{-1}$ and $\sim 97 \mathrm{ng} \mathrm{m}^{-2} \mathrm{~s}^{-1}$ for methanol and acetone above a ponderosa pine (Pinus ponderosa) plantation. Assuming an LAI of $3-4 \mathrm{~m}^{2} \mathrm{~m}^{-2}$ the acetone flux from a Norway spruce (Picea abies) canopy published by Cojocariu et al. (2004) would equate to 111 $139 \mathrm{ng} \mathrm{m}^{-2} \mathrm{~s}^{-1}$. Methanol and acetone fluxes $\left(\mathrm{T}=18^{\circ} \mathrm{C}\right)$ 
Table 5. Summary of Gradient Observations: Flux ILT (flux calculated from Inverse Lagrangian Transport Model), Flux EC (flux calculated from Eddy Covariance measurements), $\mathrm{C}$ mean uc (mean concentration above the canopy), C mean lc (mean concentration below the canopy top), mean ev (average exchange velocity calculated from ILT flux), net ev (net exchange velocity calculated from ILT flux), ev layer 1 (exchange velocity for layer one: ground to $\sim 2 \mathrm{~m}$ above ground) and ev max/min (maximum and minimum exchange velocity inferred from Fig. 5).

\begin{tabular}{|c|c|c|c|}
\hline & $\mathrm{MeOH}$ & Acetone & $\mathrm{CH}_{3} \mathrm{CHO}$ \\
\hline \multicolumn{4}{|l|}{ Day } \\
\hline Flux ILT (ng m $\left.{ }^{-2} \mathrm{~s}^{-1}\right)$ & $139 \pm 44$ & $31 \pm 8$ & $-28 \pm 8$ \\
\hline Flux EC $\left(\operatorname{ng~m}^{-2} \mathrm{~s}^{-1}\right)$ & $89 \pm 28$ & $103 \pm 56$ & - \\
\hline $\mathrm{C}$ mean uc (ppb) & 5.78 & 3.55 & 0.86 \\
\hline C mean lc (ppb) & 5.91 & 3.58 & 0.74 \\
\hline Mean ev $\left(\mathrm{cm} \mathrm{s}^{-1}\right)$ & $0.26 \pm 0.56$ & $0.01 \pm 0.3$ & $-0.46 \pm 1.68$ \\
\hline Net ev $\left(\mathrm{cm} \mathrm{s}^{-1}\right)$ & $1.32 \pm 0.40$ & $0.26 \pm 0.08$ & $-2.3 \pm 0.7$ \\
\hline ev layer 1 (soil) $\left(\mathrm{cm} \mathrm{s}^{-1}\right)$ & -0.14 & -0.05 & 0.12 \\
\hline $\mathrm{ev} \max / \min \left(\mathrm{cm} \mathrm{s}^{-1}\right)$ & $1.0 /-0.22$ & $0.45 /-0.13$ & $1.94 /-2.61$ \\
\hline \multicolumn{4}{|l|}{ Night } \\
\hline $\mathrm{C}$ mean uc (ppb) & 3.87 & 2.79 & 0.44 \\
\hline C mean lc (ppb) & 2.46 & 2.41 & 0.25 \\
\hline Mean ev $\left(\mathrm{cm} \mathrm{s}^{-1}\right)$ & $-0.30 \pm 0.45$ & $-0.11 \pm 0.15$ & $-0.32 \pm 0.48$ \\
\hline Net ev $\left(\mathrm{cm} \mathrm{s}^{-1}\right)$ & $-0.96 \pm 0.30$ & $-0.46 \pm 0.12$ & $-1.29 \pm 0.30$ \\
\hline ev layer 1 (soil) $\left(\mathrm{cm} \mathrm{s}^{-1}\right)$ & 0.06 & 0.05 & -0.32 \\
\hline \multirow[t]{2}{*}{$\mathrm{Ev} \max / \min \left(\mathrm{cm} \mathrm{s}^{-1}\right)$} & $0.06 /-0.97$ & $0.05 /-0.32$ & $0.30 /-0.88$ \\
\hline & MVK+MAC & $\mathrm{C}_{3,4}$ carbonyls & Acetic Acid+Glycolaldehyde \\
\hline \multicolumn{4}{|r|}{ ( } \\
\hline Flux ILT $\left(\mathrm{mg} \mathrm{m}^{-2} \mathrm{~h}^{-1}\right)$ & $-19 \pm 6$ & $42 \pm 11$ & $-250 \pm 83$ \\
\hline $\mathrm{C}$ mean uc (ppb) & 2.20 & 1.08 & 3.53 \\
\hline C mean lc (ppb) & 2.11 & 1.10 & 3.12 \\
\hline Mean ev $\left(\mathrm{cm} \mathrm{s}^{-1}\right)$ & $-0.065 \pm 0.15$ & $0.26 \pm 0.63$ & $-0.68 \pm 0.68$ \\
\hline Net ev $\left(\mathrm{cm} \mathrm{s}^{-1}\right)$ & $-0.33 \pm 0.10$ & $1.32 \pm 0.40$ & $-3.14 \pm 0.90$ \\
\hline ev layer 1 (soil) $\left(\mathrm{cm} \mathrm{s}^{-1}\right)$ & -0.07 & -0.33 & -0.55 \\
\hline $\operatorname{Ev} \max / \min (\mathrm{cm} / \mathrm{s})$ & $0.15 /-0.27$ & $1.34 /-0.33$ & $0.22 /-1.56$ \\
\hline \multicolumn{4}{|l|}{ Night } \\
\hline $\mathrm{C}$ mean uc $(\mathrm{ppb})$ & 1.28 & 0.70 & 1.68 \\
\hline C mean lc (ppb) & 0.63 & 0.50 & 0.86 \\
\hline Mean ev $\left(\mathrm{cm} \mathrm{s}^{-1}\right)$ & $-0.59 \pm 0.98$ & $-0.43 \pm 0.63$ & $-0.33 \pm 0.49$ \\
\hline Net ev $\left(\mathrm{cm} \mathrm{s}^{-1}\right)$ & $-2.4 \pm 1.0$ & $-1.72 \pm 0.55$ & $-1.3 \pm 0.4$ \\
\hline ev layer 1 (soil) $\left(\mathrm{cm} \mathrm{s}^{-1}\right)$ & 0.2 & -0.25 & -0.13 \\
\hline $\operatorname{Ev} \max / \min \left(\mathrm{cm} \mathrm{s}^{-1}\right)$ & $0.2 /-2.0$ & $0.2 /-1.3$ & $0.09 /-1.0$ \\
\hline
\end{tabular}

above a subalpine ecosystem consisting mostly of lodgepole pine (Pinus contorta) were on the order of $278 \mathrm{ng} \mathrm{m}^{-2} \mathrm{~s}^{-1}$ and $139 \mathrm{ng} \mathrm{m}^{-2} \mathrm{~s}^{-1}$ (Karl et al., 2002b).

3.2.4 Acetaldehyde, acetic acid, MVK+MAC and m/z 73 (Fig. 5 panels c, d, e and f)

The daytime emission profile for acetaldehyde (Fig. 5, panel c) suggests mostly deposition to the canopy. The exchange velocity at the highest level is positive and could indicate enhanced photochemical production in the surface layer. The mean exchange velocity and the net exchange velocity during the day were $-0.46 \mathrm{~cm} \mathrm{~s}^{-1}$ and $-2.3 \mathrm{~cm} \mathrm{~s}^{-1}$, respectively. While previous canopy scale measurements at forested sites (Schade and Goldstein, 2001; Karl et al., 2003, 2004) showed emissions during daytime, measurements at Duke Forest suggest mostly uptake by the loblolly pine stand, similar to observations by Rottenberger et al. (2004). The highest uptake rates correspond to the peak of the loblolly pine leaf area index (Fig. 8, Table 5). This is in contrast to our leaf level emission measurements which indicate compensation points $(2-8 \mathrm{ppb})$ well above ambient concentrations 
$(0.86 \mathrm{ppb})$ observed during the CELTIC experiment. The reason for this discrepancy is not entirely clear but could be due to the fact that potted plants grown in a greenhouse have altered their biochemical production pathways leading to an increased emission of acetaldehyde (e.g. low light levels or anaerobic conditions due to a densely crowded root system in potted plants). Another possibility would be that processes on the canopy scale (e.g. such as dry deposition) could have increased the loss under field conditions.

We have previously concluded that $\mathrm{m} / \mathrm{z} 61$ above forested sites corresponds mostly to acetic acid with minor contributions from glycolaldehyde (Karl et al., 2004). Thus, we argue that acetic acid (Fig. 5, panels e and f) is mostly deposited throughout the canopy during day and night similar to observations in other ecosystems (Kuhn et al., 2002; Sanhueza et al., 1989). We inferred mean and net exchange velocities of $-0.68 \mathrm{~cm} \mathrm{~s}^{-1}$ and $-3.14 \mathrm{~cm} \mathrm{~s}^{-1}$ during the day and $-0.33 \mathrm{~cm} \mathrm{~s}^{-1}$ and $-1.3 \mathrm{~cm} \mathrm{~s}^{-1}$ during the night, respectively. The exchange velocities close to the ground were small. Field measurements in the past indicated that acetic acid is mostly deposited to the vegetation (e.g. Kesselmeier et al., 1998; Kuhn et al., 2002; Sanhueza et al., 1989; Staudt et al., 2000; Karl et al., 2004). Daytime deposition values during this study (net ev: $-3.14 \mathrm{~cm} \mathrm{~s}^{-1}$ ) are higher than recent results obtained above a tropical forest (net ev: $-1.9 \mathrm{~cm} \mathrm{~s}^{-1}$ ) in Costa Rica, but are within the range observed above other ecosystems. Kuhn et al. (2002) calculated deposition velocity on the order of 0.18 to $0.22 \mathrm{~cm} \mathrm{~s}^{-1}$, but indicated that these might be a lower limit. Compared to measurements above a rainforest (mean daytime concentration: 1 ppb) (Karl et al., 2004), the South Eastern US is more polluted with a mean acetic acid concentration on the order of $\sim 3.5 \mathrm{ppb}$. High deposition could be caused by a compensation point driven uptake, which would be expected to be higher under more polluted conditions. On the other hand nighttime uptake is also significant, suggesting that other processes leading to the loss of acetic acid might be important.

For these compounds the dry deposition velocities calculated according to Wesely (1989) would be lower in the range of 0.27 (acetaldehyde) to 0.65 (acetic acid) $\mathrm{cm} \mathrm{s}^{-1}$ during the day and 0.02 (acetaldehyde) to 0.13 (acetic acid) $\mathrm{cm} \mathrm{s}^{-1}$ during the night.

The 1st generation oxidation products (methyl vinyl ketone (MVK)+methacrolein (MAC)) of isoprene chemistry are mostly deposited during both the day (net ev: $-0.33 \mathrm{~cm} \mathrm{~s}^{-1}$ ) and night (net ev: $-2.4 \mathrm{~cm} \mathrm{~s}^{-1}$ ). A slightly positive exchange velocity (Fig. 5 , panel e) at the top of the canopy could be caused by higher photochemical production above the canopy during the day, similar to acetaldehyde. While daytime deposition of MVK+MAC $\left(-0.33 \mathrm{~cm} \mathrm{~s}^{-1}\right)$ is significant and comparable to measurements obtained above a tropical rain forest in Costa Rica (net ev: $-0.4 \mathrm{~cm} \mathrm{~s}^{-1}$ ), it is roughly a factor of ten lower than values reported above a tropical rain forest in Amazônia using the relaxed eddy accu- mulation technique (Andreae et al., 2002).

Gradients of $\mathrm{C}_{3}+\mathrm{C}_{4}$ carbonyls on $\mathrm{m} / \mathrm{z} 73$ are depicted in Fig. 5 (panels e and f), which show a source at the canopy top and in the middle of the canopy during daytime; the ground acts as a sink. If the water cluster contributed a significant part of the signal at $\mathrm{m} / \mathrm{z} 73+$, positive exchange velocities would be expected throughout the canopy and negative or smaller exchange velocities would be expected at the canopy top due to a positive daytime latent heat flux. The overall exchange pattern indicates both biogenic and possibly atmospheric sources for compounds exhibiting $\mathrm{m} / \mathrm{z} 73^{+}$.

\section{Conclusion}

We observed significant emissions of methanol and acetone from a loblolly pine (Pinus taeda) plantation with sweetgum (Liquidambar styraciflua) understory during the CELTIC field experiment. Leaf level measurements supported these findings and were in reasonable agreement with canopy scale fluxes calculated from an Inverse Lagrangian Transport scheme. In summary our measurements support similar findings for emissions of these compounds from previous studies above other ecosystems (Schade and Goldstein, 2001; Kesselmeier and Staudt, 1999; Cojocariu et al., 2004).

The exchange of acetaldehyde exhibited a temperature dependent compensation point. Leaf level measurements of acetaldehyde showed compensation points $(>2.2 \mathrm{ppb})$ comparable to a recent study with spruce (Picea abies) needles (Cojocariu et al., 2004). Older needles had lower compensation points than younger needles, which has also been observed for tropical trees (Rottenberger et al., 2005). Canopy scale gradient measurements on the other hand showed mostly uptake suggesting much lower compensation points ( $<0.9 \mathrm{ppb})$. Lower compensation points in the canopy were also found by Rottenberger et al. (2004) under clean and polluted air conditions during the wet season in the Amazon. Two reasons could explain this discrepancy: (1) plants grown under laboratory conditions have altered their biochemical pathways compared to those grown under field conditions, or (2) dry deposition to surfaces plays an important role under field conditions. Observations by Cojocariu et al. (2004) indicated that leaf level measurements under field and laboratory conditions showed similar compensation points for spruce trees and would argue for the latter. Combined canopy and branch scale experiments under field conditions will be needed to resolve the discrepancy observed during the CELTIC experiment. These observations suggest that inappropriate comparison of biogenic OVOC emissions by Singh et al. (2004) could explain part of the variability seen by these authors.

Significant uptake of MVK+MAC and acetic acid during daytime indicates that photochemical production dominates. All oxygenated compounds exhibited a strong nocturnal loss, and the deposition velocities were much greater than assumed from traditional deposition schemes. Together 
with findings from previous studies this argues that our understanding of deposition is still limited and that the loss of oxygenated compounds is larger than assumed in current models.

The addition of ozone triggered the release of compounds commonly attributed to the oxidation of fatty acids. In addition ions exhibited $\mathrm{m} / \mathrm{z}$ ratios that would correspond to oxygenated VOCs identified from ozonolysis at vegetation surfaces such as acetone, 6-methyl-5-hepten-2-one and geranyl acetone (Fruekilde et al., 1998). Wildt et al. (2003) reported the presence of $\mathrm{C}_{6}-\mathrm{C}_{10}$ aldehydes after ozone fumigation; our measurements show mass spectral evidence of the presence of aldehydes over the entire $\mathrm{C}_{1}-\mathrm{C}_{13}$ range.

Ions corresponding to the oxygenated VOC categories (OX1-OX12) reported by Holzinger et al. (2004) were also detected and to some extent overlapped with compounds associated with ozonolysis of plant tissue. Addition of ozone before and after of the plant cuvette suggested that a substantial amount of the OX1-OX12 species originated from the reaction of ozone inside the plant and on plant surfaces (e.g. by cleavage of fatty acids) rather than formation in the air after the release of reactive terpenes (e.g. beta caryophellene). Our observations also indicate that certain ions (e.g. m/z 111, 127,129 and 145) are produced predominantly from the gas phase oxidation of reactive terpenes (e.g. sesquiterpenes) as hypothesized by Holzinger et al. (2004). These oxygenated species likely have multiple sources in a canopy (ozone-plant induced production and atmospheric reactions), which need to be taken into account when calculating potential yields of very reactive compounds. The hypothesized large emission potential of very reactive terpenes (Holzinger et al., 2004) might therefore be an upper limit. While the presence of very reactive terpenes (Went, 1960) has long been recognized the quantification remains a challenge. The ozone induced production of biogenic oxygenated compounds might increase due to the expected higher ozone levels in the future and might enhance the biogenic contribution to secondary organic aerosol formation.

Acknowledgements. The Duke Forest field study was supported by the Office of Science (BER), U.S. Department of Energy, Grant No. DE-FG02-95ER62083. The authors thank staff at the Duke FACE site for their assistance and support. We also thank J. Fuentes for helpful discussions. B. Baker and K. Jardine were supported by NSF Grant ATM-0131785. The National Center for Atmospheric Research is sponsored by the National Science Foundation. This work was also funded by EPA. We thank C. Geron as project officer.

Edited by: J. Kesselmeier

\section{References}

Andreae, M. O., Artaxo, P., Brandao, C., Carswell, F. E., Ciccioli, P., da Costa, A. L., Culf, A. D., Esteves, J. L., Gash, J. H. C., and Grace, J.: Biogeochemical cycling of carbon, water, energy, trace gases, and aerosols in Amazonia: The LBA-EUSTACH experiments, J. Geophys. Res., 107 (Part 20 Part 20), LBA 33, doi:10.1029/2001JD000524, 2002.

Baldocchi, D.: Flux footprints within and over forest canopies, Boundary-Layer Meteorology, 85(2), 273-292, 1997.

Calogirou, A., Larsen, B., and Kotzias, D.: Gas-phase terpene oxidation products: a review, Atmos. Environ., 33, 1423-1439, 1999.

Cojocariu, C., Escher, P., Haberle, K. H., Matyssek, R., Rennenberg, H., and Kreuzwieser, J.: The effect of ozone on the emission of carbonyls from leaves of adult Fagus sylvatica, Plant Cell and Environment, 28(5), 603-611, 2005.

Cojocariu, C., Kreuzwieser, J., and Rennenberg, H.: Correlation of short-chained carbonyls emitted from Picea abies with physiological and environmental parameters, New Phytologist, 162, 717-727, 2004.

de Gouw, J., Warneke, C., Karl, T., Eerdekens, G., van der Veen, C., and Fall, R.: Sensitivity and specificity of atmospheric trace gas detection by proton-transfer-reaction mass spectrometry, International Journal of Mass Spectrometry, 223(1-3), 365-382, $2003 \mathrm{a}$.

de Gouw, J. A., Goldan, P. D., Warneke, C., Kuster, W. C., Roberts, J. M., Marchewka, M., Bertman, S. B., Pszenny, A. A. P., and Keene, W. C.: Validation of proton transfer reaction-mass spectrometry (PTR-MS) measurements of gas-phase organic compounds in the atmosphere during the New England Air Quality Study (NEAQS) in 2002, J. Geophys. Res., 108(D21), 2003b.

Fall, R.: Biogenic emissions of volatile organic compounds from higher plants, in: Reactive hydrocarbons in the atmosphere, edited by: Hewitt, C. N., Academic Press, New York, 41-96, 1999.

Fall, R.: Abundant oxygenates in the atmosphere: A biochemical perspective, Chemical Reviews, 103, 4941-4951, 2003.

Fall, R. and Benson, A.: Leaf methanol - the simplest natural product from plants, Trends Plant Sci., 1, 296-301, 1996.

Fall, R., Karl, T., Hansel, A., Jordan, A., and Lindinger, W.: Volatile organic compounds emitted after leaf wounding: On-line analysis by proton-transfer-reaction mass spectrometry, J. Geophys. Res., 104(D13), 15963-15 974, 1999.

Farquhar, G. D., Caemmerer, S. V., and Berry, J. A.: A Biochemical-Model of Photosynthetic $\mathrm{Co} 2$ Assimilation in Leaves of C-3 Species, Planta, 149(1), 78-90, 1980.

Fruekilde, P., Hjorth, J. N. R., Kotzias, D., and Larsen, B.: Ozonolysis at vegetation surfaces: A source of acetone, 4-oxopentanal, 6-methyl-5-hepten-2-one and geranyl acetone, Atmos. Environ., 32(11), 1893-1902, 1998.

Galbally, I. E. and Kirstine, W.: The Production of Methanol by Flowering Plants and the Global Cycle of Methanol, J. Atmos. Chem., 43(3), 35, 2002.

Geron, C., Rasmussen, R., Arnts, R. R., and Guenther, A.: A review and synthesis of monoterpene speciation from forests in the United States, Atmos. Environ., 34(11), 1761-1781, 2000.

Graus, M., Schnitzler, J. P., Hansel, A., Cojocariu, C., Rennenberg, H., Wisthaler, A., and Kreuzwieser, J.: Transient release of oxygenated volatile organic compounds during light-dark transitions in grey poplar leaves, Plant Physiology, 135(4), 1967-1975, 2004.

Guenther, A., Hewitt, C. N., Erickson, D., and Fall, R.: A global model of natural volatile organic compound emissions, J. Geophys. Res., 100(D/5), 8873-8892, 1995. 
Guenther, A. B. and Hills, A. J.: Eddy covariance measurement of isoprene fluxes, J. Geophys. Res., 103(D11), 13, 1998.

Hatanaka, A.: The fresh green odor emitted by plants, Food Reviews International, 12(3), 303-350, 1996.

Heikes, B. G., Chang, W. N., Pilson, M. E. Q., Swift, E., Singh, H. B., Guenther, A., Jacob, D. J., Field, B. D., Fall, R., Riemer, D., and Brand, L.: Atmospheric methanol budget and ocean implication, Global Biogeochemical Cycles, 16(4), art. no.-1133, 2002.

Holzinger, R., Lee, A., Paw, K. T. U., and Goldstein, A. H.: Observations of oxidation products above a forest imply biogenic emissions of very reactive compounds, Atmos. Chem. Phys., 5, 67-75, 2004,

SRef-ID: 1680-7324/acp/2005-5-67.

Jacob, D. J., Field, B. D., Jin, E. M., Bey, I., Li, Q., Logan, J. A., Yantosca, R. M., and Singh, H. B.: Atmospheric budget of acetone, J. Geophys. Res., 107 (Part 9/10 Part 9/10), ACH 5, doi:10.1029/2001JD000694, 2002.

Janson, R., De Serves, C., and Romero, R.: Emission of isoprene and carbonyl compounds from a boreal forest and wetland in Sweden, Agricultural and Forest Meteorology, 98-99, 671-681, 1999.

Karl, T., Curtis, A. J., Rosenstiel, T. N., Monson, R., and Fall, R.: Transient releases of acetaldehyde from tree leaves-products of a pyruvate overflow mechanism?, Plant Cell and Environment, 25, 1121-1131, 2002a.

Karl, T., Guenther, A., Spirig, C., Hansel, A., and Fall, R.: Seasonal variation of biogenic VOC emissions above a mixed hardwood forest in northern Michigan, Geophys. Res. Lett., 30(23), 2186, 2003.

Karl, T., Harren, F. J. M., Warneke, C., de Gouw, J., Grayless, C., and Fall, R.: Senescing grass crops as regional sources of reactive VOCs, J. Geophys. Res.-Atmos., 110(D15), D15302, doi:10.1029/2005JD005777, 2005.

Karl, T., Potosnak, M., Guenther, A., Clark, D., Walker, J., Herrick, J. D., and Geron, C.: Exchange processes of volatile organic compounds above a tropical rain forest: Implications for modeling tropospheric chemistry above dense vegetation, J. Geophys. Res., 109(D18), D18306, doi:10.1029/2004JD004738, 2004.

Karl, T. G., Spirig, C., Rinne, J., Stroud, C., Prevost, P., Greenberg, J., Fall, R., and Guenther, A.: Virtual disjunct eddy covariance measurements of organic compound fluxes from a subalpine forest using proton transfer reaction mass spectrometry, Atmos. Chem. Phys., 2, 279-291, 2002b,

SRef-ID: 1680-7324/acp/2002-2-279.

Katul, G., Hsieh, C. I., Bowling, D., Clark, K., Shurpali, N., Turnipseed, A., Albertson, J., Tu, K., Hollinger, D., Evans, B., Offerle, B., Anderson, D., Ellsworth, D., Vogel, C., and Oren, R.: Spatial variability of turbulent fluxes in the roughness sublayer of an even-aged pine forest, Boundary-Layer Meteorology, 93(1), 1-28, 1999.

Kesselmeier, J.: Exchange of short-chain oxygenated volatile organic compounds (VOCs) between plants and the atmosphere: A compilation of field and laboratory studies, J. Atmos. Chem., 39(3), 219-233, 2001.

Kesselmeier, J., Bode, K., Gerlach, C., and Jork, E. M.: Exchange of atmospheric formic and acetic acids with trees and crop plants under controlled chamber and purified air conditions, Atmos. Environ., 32(10), 1765-1775, 1998.
Kesselmeier, J. and Staudt, M., Biogenic volatile organic compounds (VOC): An overview on emission, physiology and ecology, J. Atmos. Chem., 33, 23-88, 1999.

Kreuzwieser, J., Kuhnemann, F., Martis, A., Rennenberg, H., and Urban, W.: Diurnal pattern of acetaldehyde emission by flooded poplar trees, Physiologia Plantarum, 108(1), 79-86, 2000.

Kuhn, U., Rottenberger, S., Biesenthal, T., Ammann, C., Wolf, A., Schebeske, G., Oliva, S. T., Tavares, T. M., and Kesselmeier, J.: Exchange of short-chain monocarboxylic acids by vegetation at a remote tropical forest site in Amazonia, J. Geophys. Res., 107(D20), 8069, doi:10.1029/2000JD000303, 2002.

Lindinger, W., Jordan, A., and Hansel, A.: Proton-transfer-reaction mass spectroscopy (PTR-MS): on-line monitoring of volatile organic compounds at pptv levels, Chem. Society Reviews, 27, 347-534, 1998.

McLaren, R., Singleton, D. L., Lai, J. Y. K., Khouw, B., Singer, E., $\mathrm{Wu}, \mathrm{Z}$., and Niki, H.: Analysis of motor vehicle sources and their contribution to ambient hydrocarbon distributions at urban sites in Toronto during the Southern Ontario Oxidants Study, Atmos. Environ., 30(12), 2219-2232, 1996.

Niinemets, U., Loreto, F., and Reichstein M.: Physiological and physicochemical controls on foliar volatile organic compound emissions, Trends in Plant Science, 9(4), 180-186, 2004.

Northway, M. J., de Gouw, J. A., Fahey, D. W., Gao, R. S., Warneke, C., Roberts, J. M., and Flocke, F.: Evaluation of the role of heterogeneous oxidation of alkenes in the detection of atmospheric acetaldehyde, Atmos. Environ., 38(35), 6017-6028, 2004.

Raupach, M. R.: Applying Lagrangian fluid mechanics to infer scalar source distributions from concentration profiles in plant canopies, Agricultural and Forest Meteorology, 47(2-4), 85-108, 1989.

Rottenberger, S., Kuhn, U., Wolf, A., Schebeske, G., Oliva, S. T., Tavares, T. M., and Kesselmeier, J.: Exchange of short-chain aldehydes between Amazonian vegetation and the atmosphere, Ecological Applications, 14(4), S247-S262, 2004.

Rottenberger, S., Kuhn, U., Wolf, A., Schebeske, G., Oliva, S. T., Tavares, T. M., and Kesselmeier, J.: Formaldehyde and acetaldehyde exchange during leaf development of the Amazonian deciduous tree species Hymenaea courbaril, Atmos. Environ., 39(12), 2275-2279, 2005.

Sanhueza, E., Donoso, L., Scharffe, D., and Crutzen, P. J.: Organic and inorganic acids in rain from a remote site of the Venzuelan savannah, Tellus, 41B, 170-176, 1989.

Schade, G. W. and Custer, T. G.: OVOC emissions from agricultural soil in northern Germany during the 2003 European heat wave, Atmos. Environ., 38(36), 6105-6114, 2004.

Schade, G. W. and Goldstein, A. H.: Fluxes of oxygenated volatile organic compounds from a ponderosa pine plantation, J. Geophys. Res., 106(D3), 3111-3123, 2001.

Schade, G. W. and Goldstein, A. H.: Plant physiological influences on the fluxes of oxygenated volatile organic compounds from ponderosa pine trees, J. Geophys. Res., 107 (Part 9/10 Part 9/10), ACH 2, doi:10.1029/2001JD000532, 2002.

Singh, H. B., Salas, L. J., Chatfield, R. B., Czech, E., Fried, A., Walega, J., Evans, M. J., Field, B. D., Jacob, D. J., Blake, D., Heikes, B., Talbot, R., Sachse, G., Crawford, J. H., Avery, M. A., Sandholm, S., and Fuelberg, H.: Analysis of the atmospheric distribution, sources, and sinksof oxygenated volatile organic chemicals based on measurements over the Pacific during TRACE-P, 
J. Geophys. Res., 109, doi:10.1029/2003JD003883, 2004.

Spirig, C., Neftel, A., Ammann, C., Dommen, J., Grabmer, W., Thielmann, A., Schaub, A., Beauchamp, J., Wisthaler, A., and Hansel, A.: Eddy covariance flux measurements of biogenic VOCs during ECHO 2003 using proton transfer reaction mass spectrometry, Atmos. Chem. Phys., 5, 465-481, 2005,

SRef-ID: 1680-7324/acp/2005-5-465.

Staudt, M., Wolf, A., and Kesselmeier, J.: Influence of environmental factors on the emissions of gaseous formic and acetic acids from orange (Citrus sinensis L.) foliage, Biogeochemistry, 48(2), 199-216, 2000.

Steinbrecher, J. and Rabong, R.: Emission of terpenoids and C2C6 hydrocarbons by Norway spruce: phytotron experiment and field studies, edited by: Borrell, P., Borrell, P. M., and Seiler, W., Proceedings of EUROTRAC Symposium '94 The Hague, The Netherlands: SPB Academic Publishing, 502-505, 1994.

Strong, C., Fuentes, J. D., and Baldocchi, D.: Reactive hydrocarbon flux footprints during canopy senescence, Agricultural and Forest Meteorology, 127(3-4), 159-173, 2004.

Stroud, C., Makar, P. A., Karl, T., Guenther, A., Geron, C., Turnipseed, A. A., Nemitz, E., Baker, B., Potosnak, M., Fuentes, J. D., McCarthy, H., and Oren, R.: Role of CanopyScale Photochemistry in Modifying Biogenic-Atmosphere Exchange of Reactive Terpene Species: Results from the CELTIC Field Study, J. Geophys. Res.-Atmos., 110, D17303, doi:10.1029/2005JD005775, 2005.
Warneke, C., Karl, T., Judmaier, H., Hansel, A., Jordan, A., Lindinger, W., and Crutzen, P. J.: Acetone, methanol, and other partially oxidized volatile organic emissions from dead plant matter by abiological processes: Significance for atmospheric HOx chemistry, Global Biogeochemical Cycles, 13(1), 9-17, 1999.

Went, F. W.: Blue hazes in the atmosphere, Nature, 187(4738), 641643, 1960.

Wesely, M.: Parameterization of surface resistance to gaseous dry deposition in regional-scale numerical models, Atmos. Environ. 23, 1293-1304, 1989.

Wildt, J., Kobel, K., Schuh-Thomas, G., and Heiden, A. C.: Emissions of Oxygenated Volatile Organic Compounds from Plants Part II: Emissions of Saturated Aldehydes, J. Atmos. Chem., 45(2), 24, 2003. 